\title{
買物行動モデルによる東京都区部における小売業の 均衡的立地パターンとその動態分析
}

\author{
張 長 平*
}

\begin{abstract}
本稿は, 買物行動モデルに依拠した，小壳業の需要一供給の均衡状態をもたらすバランスメカニズムを理 論的根拠として, 東京都区部における小売業の均衡的立地パターンを尊き, それを基準として現在の小売業 立地パターンを評価した。ささらに，小売業の均衡的立地パターンを動態的に分析した.

その結果，（1）東京都区部における吸収均衡売場面積および吸収均衡差（吸収均衡売場面積之実際の売 場面積の差）は地域的差異を示すこと,（2）吸収均衡差の地域的差異は耐久消費財の年間販売額比率, 大 型店の支持人口, 小壳業の吸収人口および来区の平均時間距離の各社会・経済的特性要素と密接な関係があ ること,（3）東京都区部では経済規模パラメー夕の減少に伴い，小売業の均衡的立地パターンは凝集型か ら均一型へと変化していくこと, 他方, 距離減衰パラメータの減少, および時間距離の減少によって, 小売 業の均衡的立地パターンは均一型から凝集型へと変化していくこと，などが明らかになった。
\end{abstract}

\section{I はじめに}

\section{1. 従来の研究}

小売業の立地に対する消費者行動の観点からの考 察は, 1960 年代半ばから商業地理学の 1 つの重要 な課題となった。こ机に伴って多くの研究成果が報 告されてきたが，とくに注目されるものは，Wilson （1974）におけるエントロピー理論の商業地理学的 問題への適用であった，そこでは，消費者・経営者 双方の要求, 換言すれば需要と供給を統合した，式 （1）のような買物行動モデルが構築されている.

$$
T_{i j}=\frac{O_{i} W_{j}^{\alpha} \exp \left(-\beta c_{i j}\right)}{\sum_{j} W_{j}{ }^{\alpha} \exp \left(-\beta c_{i j}\right)}
$$

ただし， $T_{i j}$ は地区 $i$ から地区 $j$ へ訪れる買物卜 リップ数, $O_{i}$ は地区 $i$ から発生する買物トリップ 総数, $W_{j}$ は地区 $j$ の小売業売場面積, $c_{i j}$ は地区 $i$ と地区 $j$ の間の距離, $\alpha$ は経済規模パラメー夕, $\beta$ は距離減衰パラメータである。 $W_{j}{ }^{a}$ は一般に吸 収魅力度と呼ばれるものである.

ところで，この式について地区 $j$ を想定した場合，
地区 $j$ に吸収される買物トリップ総数 $D$; は, 地区 $j$ に対する消費者の一種の需要量とみなすことがで きる．また，地区 $j$ における単位売場面積当たりの 吸収買物トリップ数 (買物吸収密度) $k_{j}$ を想定す れば， $k_{j} \cdot W_{j}$ は地区 $j$ が保有する商業施設規模 （売場面積）が吸収しうる潜在的買物トリップ数を 表わすと考えられ，この商業施設の小売供給量とみ なすことができる，小売における需要と供給が均衡 する状況が想定できるが，その場合，一般に，均衡 状態は式（2）のような関係が成立することである といえる。

$$
D_{j}=\sum_{i} \frac{O_{i} W_{j}^{\alpha} \exp \left(-\beta c_{i j}\right)}{\sum_{j} W_{j}^{\alpha} \exp \left(-\beta c_{i j}\right)}=k_{i} W_{j}
$$

換言すれば，すべての地区の小壳業が完全競争の 状態にあり，もし特定の地区において吸収買物トリ ップ数が多く，売場面積が少ない，すなわち，高利 益を得る地区があれば，低利益の地区での小売業は その高利益の地区へ移動する。しかし，この移動は 無限に行なわれるわけではない，それは，高利益地 区への移動はその地区への小売業の新規参入を意味 し，それによって高利益をめぐる競争が激化して， 
どの小売業ももはや利益を得ることができなくなる からである。 その結果, ある地域内のどの地区にお いても得られる利益は同一になる。これは, 吸収買 物トリップ総数 $D_{j}$ が売場面積 $W_{j}$ の潜在的吸収量 $k_{j} \cdot W_{j}$ と等しい状態が出現し, 方程式 (2) が成 立することを意味する。この状態が実現すれば，す べての地区の売場面積はその地区に吸収された買物 トリップ総数に対して均衡しているといえる.この 状態は吸収均衡状態, 方程式 (2) は吸収均衡状態 方程式，そして吸収均衡状態方程式によって推定さ れる地区の売場面積は吸収均衡值（あるいは, 吸収 均衡売場面積）と，それぞれ呼ばれる．以上に述べ たことは, 従来の研究ではバランスメカニズムと呼 ばれている1) (Harris and Wilson, 1978; Wilson and Clarke, 1979; Clarke, 1981; Crouchley, 1987).

以上のことから理解されるように，需給関係の均 衡状態の概念を導入した吸収均衡状態方程式は，各 地区における需要と供給が完全に均衡するという理 想的な状況がみられる場合, 買物行動がどうなるか を示すモデルといえる.

上述したような意味をもつ，買物行動モデルに基 づく小売業の均衡的立地パターンに関する研究は, 次の 3 つに大別される.

第 1 は理論的研究である. 理論的研究では, カ夕 ストロフィー理論によって, 吸収均衡状態方程式 （2）に含まれている環境パラメー夕 $\alpha, \beta, k$, の臨 界值を識別し, パラメー夕の变動が地区の吸収均衡 値へどのような影響を与えるかについて考察し，そ れによって吸収均衡值の空間的パターンの構造やそ の安定性などを分析する一連の研究がある(Harris and Wilson, 1978; Wilson and Clarke, 1979; Clarke and Wilson, 1983; Clarke, 1981, 1985). それに関連して, 近年, 買物行動モデルに基づく吸 収均衡値の研究において, 買物行動の発生流動量を 外生変数之おく, 新たな理論的研究が導入された
(Harris et al., 1982). さらに, Fotheringham and Knudsen（1986）は小売業が立地する地区の 相対的位置を考慮した際の吸収均衡値を導入してい る.すなわち, Wilson の置物行動モデルを Fotheringham（1983）の競合着地モデルにおきかえる ことにより, 小売業の吸収均衡売場面積を小売業立 地地区の相対位置に関連づけ，それによって推定さ れる吸収均衡売場面積が対象地域の地区の“地図パ ターン”効果を受けないようにしている.

第 2 は買物行動モデルに基づく吸収均衡値の数值 シミュレーションの研究である. 一般的には, 数学 モデルは，それによって地域的パターンや発展モー ドを直接的に描出するのは困難であるという性質を もっている，その困難を回避する1つの方法が数值 シミュレーションであるが, これは数学モデルによ って表わされる内容を具体的, 時空間的に再現する ことであり，それによってモデルが評価され，理論 的研究に重要な役割を果たすと考えられている. 数 值シミュレーションはいわば仮説的な研究地域に対 し, 仮想的な買物行動流デー夕を利用し, 吸収均衡売 場面積の空間的パターンや発展モードのシミュレー ションを行なうものである (Wilson and Clarke, 1979; Beaumont et al., 1981a, b; Clarke and Wilson, 1983; Clarke, 1985). たとえば, Clarke and Wilson（1983）は723の地区からなる地域を 仮定し, 施設規模変化のメカニズム2)に基づいて数 値シミュレーションを行なった結果, 吸収均衡値の 空間的パターンの变化を明らかにした.

第 3 は買物行動モデルに基づく吸収均衡値の地域 性とその動態的分析の理論について, 実際の調查資 料から現実の地域で検証する実証的研究である。こ の実証的研究は比較的遅れていたといわれている。 実証的研究に関しては，おもにWilson らの研究グ ループを中心にして行なわれている. 彼らの研究は いずれもリーズ市，あるいはリーズ都市圈において の小売業のシステムを研究対象として実施したもの 
である.これらの研究では Wilson and Clarke (1979）および Clarke（1985）がリーズ市あるい はリーズ都市圈における小売業システムを分析し， とくに，バランスメカニズムに含まれているパラメ 一夕を変化させ, 吸収均衡值の空間的パターンの変 動を考察した。

日本では空間行動の地域性を都市構造と関連づけ て考察する研究例もみられる。奥野（1966）は東京 都区部を対象地域として，吸収交通の地域性と人 ロ・土地利用之の関係を考察し，東京都区部におけ る吸収交通の目的形態（通学，通勤，買物など）は, 各地域のそれぞれの目的に関係する施設規模, 分布 状態などと深い関係があるという結果を得た．高阪 （1975）は地域住民の買物行動がほぼ完結するよう なシティー・レベルの商圈を選定し, シティー・レ ベルの商圈の内部における地域住民の買物行動によ って形成されるシティー・レベルの商圈の内部構造 を究明した。

\section{2. 本研究の目的と方法}

以上述べた，買物行動モデルに基づく小売業の均 衡状況下の立地パターンに関する従来の研究は, 理 論的研究もしくは数值シミュレーションを中心とし て行なわれており, 実証的研究, とくにその動態的 な分析については現段階で不十分である。なお筆者 の瞥見の限りでは, 吸収均衡差（すなわち, 実際の 売場面積と吸収均衡売場面積との差）についての議 論は事例が少なく, 吸収均衡差の地域パターンの形 成要因を追求する分析もほとんどなされていないと いえる。

本研究はこれらの従来の研究の問題点に着目しな がら, 吸収均衡値の地域的特徴とその動態的変化を 実証的に考察することを課題とする，すなわち，既 存の理論的研究と数值シミュレーション法を踏まえ たうえで, 現実の小売業の空間的需給形態とその均 衡的な形態との間の関係の解明を試みる.
本研究は, 小売業に関する需要と供給の間の関係 が空間的に均衡する状態を前提とし，東京都区部に おける小売業システムを研究対象としてその立地パ ターンを導き，その地域的特徵を考察するとともに， それを基準として現在の小売業の立地パターンを評 価する.さらに，小売業システムに含まれている社 会・経済の外的要因之, 経営者の経営活動と消費者 の買物行動の内的要因の变化を前提条件として想定 したうえで，上述の立地パターンについて数值シミ ユレーションを行なう。そのシミュレーションの結 果は, 将来の小売業の立地パターンを予測する $1 つ$ の重要な参考基準となる.

この目的を実現するため, 本研究の分析はバラン スメカニズムの立場より，吸収均衡状態方程式 (2) に基づいて以下のように進められる，まず，第 2 章 では，東京都区部における小売業システムの状況を 反映する, 吸収均衡状態方程式（2）に含まれる環 境パラメー夕 $\left(\alpha, \beta, k_{j}\right)$ を推定する. 次に， そ の吸収均衡状態方程式 (2) から, 修正ニュートン 法を用いて吸収均衡值（吸収均衡売場面積 $W_{j}$ ) を 求める. この值の地域的分布から, 均衡状態下の小 壳業の立地パターンを導出する。 さらに，現実の小 売業の立地パターンを評価するために, 実際の売場 面積と吸収均衡売場面積との差（すなわち, 吸収均 衡差）の地域的分布を考察し, 吸収均衡差に関連す る社会・経済的要因の抽出を行なう。 その際, 吸収 均衡差を目的变数, 地区別の小売業属性, 地区の近 接性と中心性，大型店の属性などの社会・経済特性 の要素を説明变数とする逐次回帰分析を行ない，吸 収均衡差に大きな影響をもつ説明变数を選定する。

第 3 章では, 吸収均衡値の動態的分析を実施するた めに, 買物トリップ発生量を外生変数とし, それに 関する予測モデルを構筑し, 将来の買物トリップ発 生量を予測する。 その予測結果を投入デー夕とし, 吸収均衡状態方程式の諸パラメー夕を変化させるこ とによって, 東京都区部における小売業の吸収均衡 


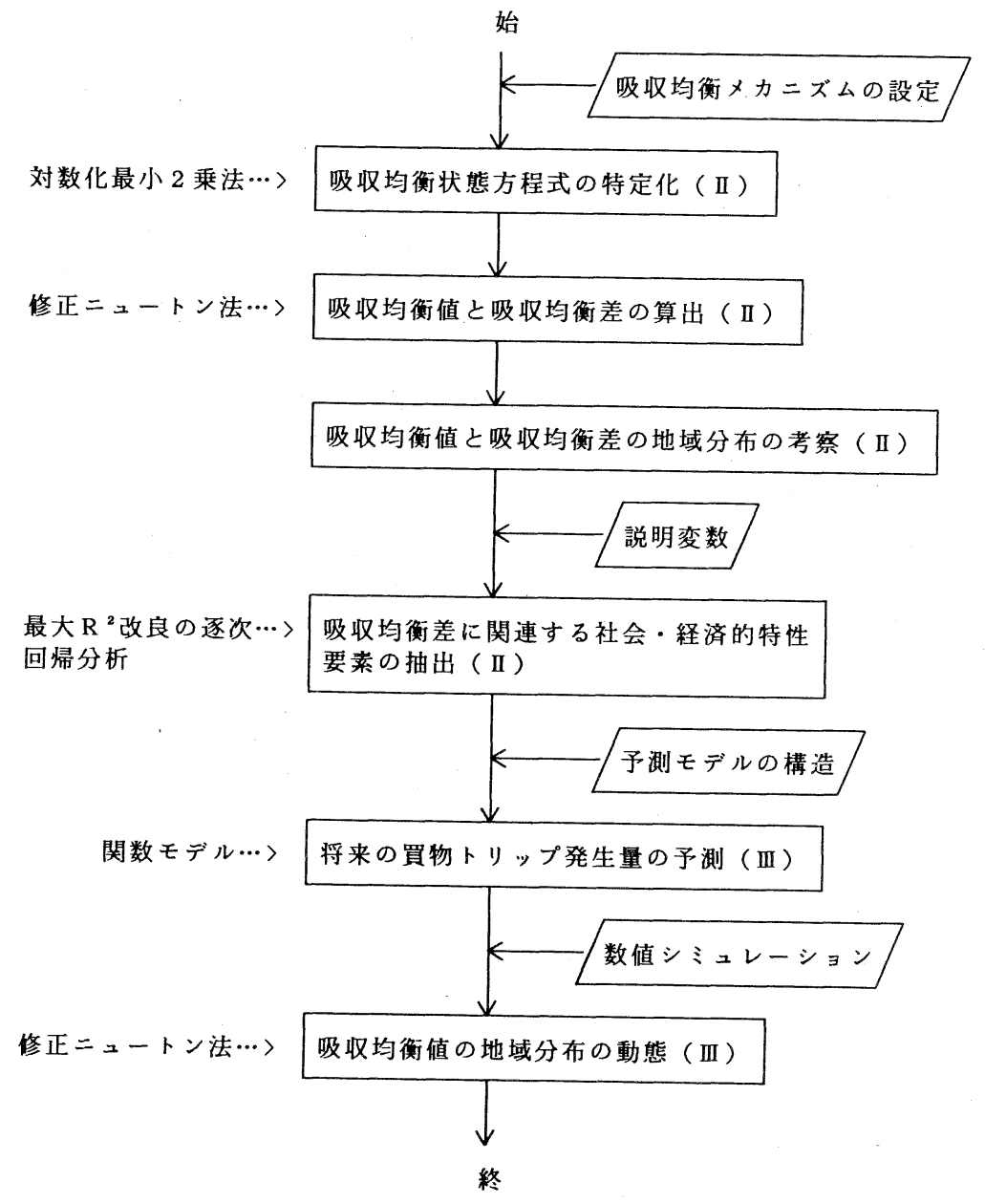

第 1 図研究の手順之手法 括弧内の口ーマ数字は該当章を示す.

Fig. 1 Flow chart of the study

売場面積の地域パターンの動態を考察する．以上の 研究手順と研究手法をフロー図にまとめると第 1 図 のようになる.

対象地域として東京都区部を選定したが，それに は次の 2 つの理由がある. 1 つは, 研究視点の性格 上, 地域住民の買物行動がほぼ完結するような地域 的範囲を選定する必要があるためである．東京都区 部は一応の完結性をもつ地域であると考えられる. これは東京都区部内で吸収される買物トリップ数の 約 93\% が同地域内で発生するからである31.もう
1 つは, 本研究の目的の 1 つである動態的分析を行 なうにあたって, 買物トリップ発生量を予測する場 合に, 研究対象地域の範囲が広くなるにつれて計算 誤差が累積し，計算精度が悪化することによる。し たがって, 比較的小規模地域でありながら, 完結性 をもつ東京都区部は, 研究対象地域として適切であ ると考えられる。

買物行動モデルに基づく小売業の均衡的立地パ夕 ーンに関する分析の理論は, 各種の施設（たとえば, 住宅, オフィス, 医療機関, 文化・スポーツ施設な 
ぞ）の立地問題に適用することができる，本研究は， 買物行動モデルを利用するが，このモデルに投入す る流動主体は，住民の買物トリップである。これに ついては，1978 年東京都市圈のパーソントリップ 調查の集計結果（東京都市圈交通計画委員会, 1980) を基本資料とし，パーソントリップ調査の中ゾーン， すなわち行政区を単位地区として採用する。 また， 東京都 23 区に関する社会・経済的な諸要素につい ての統計資料は『1979 年通産省商業統計表』, 『1979 年東京都商業統計調查報告書』, 『1978 年東京都年 鑑』，東洋経済新報社による『1979 年地域経済総 覽』によっている.

\section{II＼cjkstart東京都区部における小売業の 均衡的立地パターンの分析}

都市における小売業の均衡的立地パターンを分析 する方法は多数のものがある. 本研究は, 前章で述 べたように，小壳業の需給関係が均衡していること を前提とした場合の小売業の立地，換言すれば，均 衡的立地という一種の理念的な立地の導出を 1 つの 目的としている。 それゅえ，この均衡状態を前提と した買物行動モデルの吸収均衡状態方程式から推定 される小売業の均衡的立地パターン，具体的にいえ ば吸収均衡值（吸収均衡売場面積）の分布パターン を分析する方法をとることが最も適切であるといえ る. そこで，初めに，吸収均衡状態方程式における 環境パラメー夕と呼ばれる経済規模パラメー夕, 距 離減衰パラメー夕, 買物吸収密度の 3 つの統計量を 推定し，それによって均衡状態方程式を特定化する.
次いで，この特定化された方程式に基づいて，理念 的な小売業の均衡的立地パターンを表示する吸収均 衡值を導出し, これと実際の小売業売場面積との相 違つまり吸収均衡差を求めることによってこれを評 価する．さらに，吸収均衡差を生ぜしめる地域の社 会・経済的条件の抽出を行なうことにする.

1. 吸収均衡状態方程式のキャリブレーション

1）経済規模パラメータと距離減衰パラメータの 推定

経済規模パラメー夕 $\alpha$ と距離減衰パラメータ $\beta$ を 式（1）を利用して推定する場合に従来はさまざま な方法がとられてきたが，十分確立された方法はま だ存在していない，Stetzer（1976）は非線形最小 2 乗法 (NLLS), 最小カイ 2 乗法 (MCS), 最尤 基準法（MLC），通常最小 2 乗法 1 型（OLS 1), 通常最小 2 乗法 2 型 (OLS 2), 一般最小 2 乗法 (GLS) など 6 つのパラメー夕推定法をあげ，それ らの方法の比較検討を行ない，比較的秀れたものは Nakanishi and Cooper（1974）の考案した通常 最小 2 乗法 2 型 (これ以後, Nakanishi-Cooper 法 と呼ぶ)であるという結論を得た。 その後, Baxter （1979）と Baxter and Ewing（1979）は新型の通 常最小 2 乗法 2 型を提案した(以後, Baxter-Ewing 法と呼ぶ)。これはNakanishi-Cooper 法に比べて 操作の点で簡単である. Baxter-Ewing法と Nakanishi-Cooper 法はいずれも非線形の買物行動モデ ルを対数化して線形モデルへ变形し，通常最小 2 乗 法を用いてパラメー夕を推定するものである4).

第 1 表 経済規模パラメータ亡距離減衰パラメータの推定値

Table 1 Estimated values of the scale economies parameter and the distance parameter

\begin{tabular}{l|l|l|l|l}
\hline & \multicolumn{2}{|c|}{ Baxter-Ewing 法 } & \multicolumn{2}{c}{ Nakanishi-Cooper 法 } \\
\hline 観察値 $T_{i j}+$ & 0.5 & 0.01 & 0.5 & 0.01 \\
\hline 経済規模パラメータ $\alpha$ & 1.2 & 1.6 & 1.4 & 1.8 \\
距離減衰パラメータ $\beta$ & 0.16 & 0.20 & 0.14 & 0.17 \\
決定係数 & 0.97 & 0.98 & 0.96 & 0.97 \\
\hline
\end{tabular}




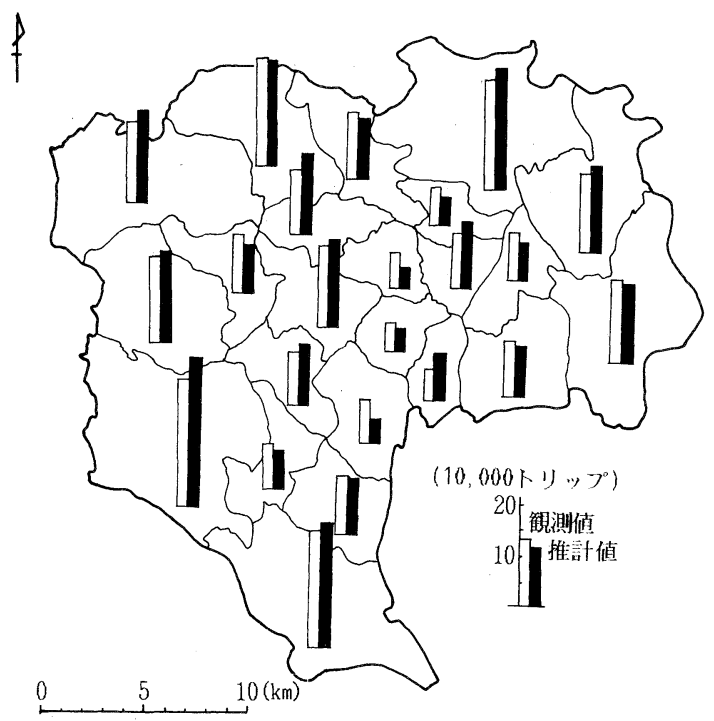

第2 図東京都区部における買物吸収トリップの推計 值亡観测値の地域的分布（1978 年）

（観測值は，東京都市圈交通計画委員会，(1980）による).

Fig. 2 Distribution of the estimates and the observations of the pulled shopping trips in the Tokyo 23-ward area

本研究では, Baxter-Ewing 法と NakanishiCooper 法の両方法を用いて, 両方法で問題となる $T_{i j}$ のデー夕値として 0.5 あるいは 0.01 をあてる5) ことにして, 両パラメータの推定を行なった。その 結果をまとめると, 第 1 表のようになる. 両方法で の決定係数が示す適合度はともにかなり高いと判断 できる。このことから両方法ともパラメー夕推定法 として適当なものといえる，そこで，決定係数がよ り高い Baxter-Ewing 法によって推定されたパラ メータの值を採用し，これに基づくモデルから計算 された買物トリップの吸収推計值を求めた。この推 計值および観測值の空間的分布を図化すると，第 2 図のようになる。これによると，推計值と観測值と の間の差はかなり小さいといえる。全体的に推計値 が観測値を上回るプラスの残差をとる区は，小壳業 売場面積が大きな区とほぼ一致する。すなおち，都 心部における中央区, 副都心の 3 区（豊島・新宿・
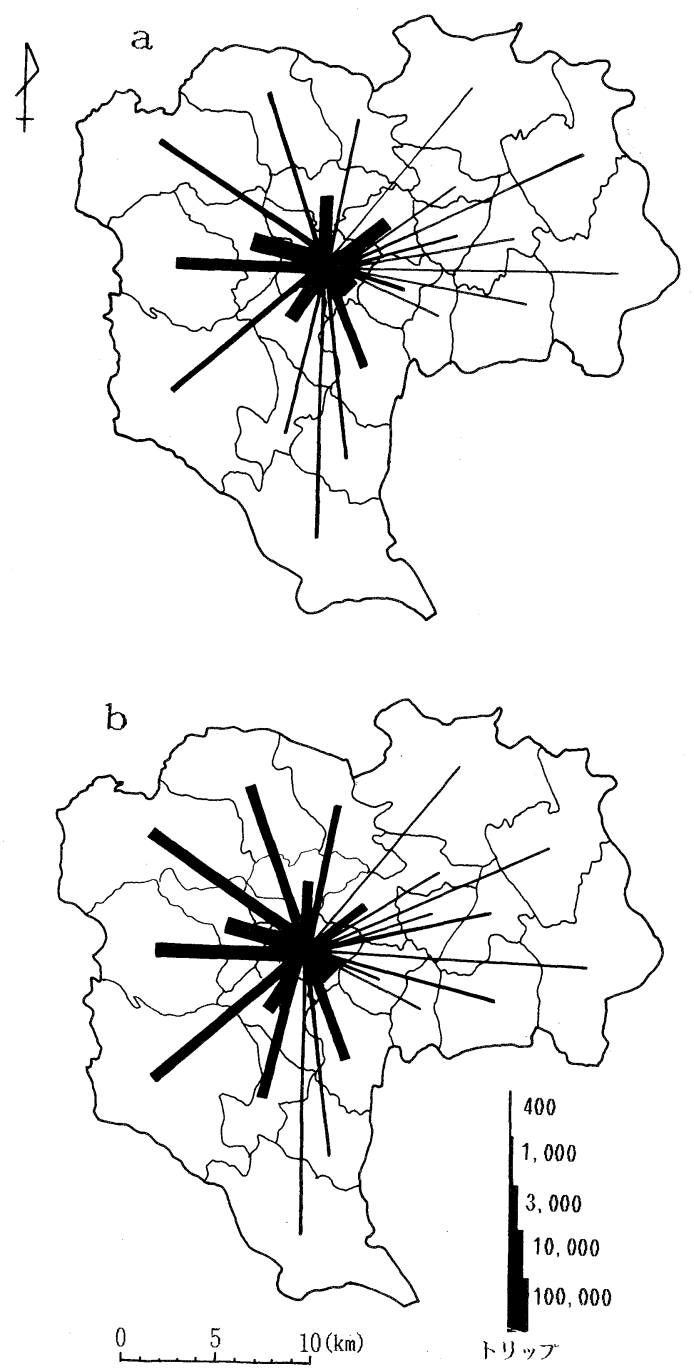

第3 図新宿区への買物トリップの推定流動と観測流 動 (1978 年)

\section{a : 推定流動 b : 観測流動}

（観測値は，東京都市圈交通計画委員会，(1980）による).

Fig. 3 Estimated and observed flow of shopping trips to Shinjuku-ku

橴谷）とその周辺の大部分の区がこれに該当する. その都心，副都心の区と周辺の大部分の区との中間 に位置する諸区にはマイナスの残差がみられる。こ れらの結果は，買物行動モデルが小売業の売場面積 の関数であることと, 推定値の合計と観測值の合計 
が必ず等しいということから容易に予想されること である、さらに，モデルを詳細に評価するために， 東京都において最大の小売業集積地の1つであり， それに郊外交通機関と市街地交通機関との最大の結 節点でもある新宿区を例にとり，モデルの推定結果 と実際のパーソントリップ調査の買物行動パターン の差異を観察する。第 3 図の $\mathrm{a}$ と $\mathrm{b}$ を比較すると, モデルによる新宿区への流入買物トリップの分布パ ターンは実際のそれと類似している。すすおち，両 図とも，西部の各区から新宿区への流入トリップは 東部の各区の場合よりかなり多く，また，新宿区か らの距離によって同地区を核とする同心円状にトリ ップ数が聥減しているという特徴を示している。な お，観測值の分布パターンに比べると，モデルによ る推計值の分布パターンは距離派減の影響が大きく 作用していることが示唆される.

以上のように, 買物行動モデルにおける経済規模 パラメー夕 $\alpha$ と距離減衰パラメー夕 $\beta$ が東京都区部 における実際の買物トリップの分布パターンに近似 するように推定された。このことは，東京都区部の 小売業の需給関係が均衡しているということを前提 としたときの小売業の均衡的立地パターンを指標化 する吸収均衡値を導く吸収均衡状態方程式が， $\alpha$ と ßについて特定化されたことを意味する.

2）買物吸収密度の設定

吸収均衡状態方程式 (2) 少ら吸収均衡値 $\left(W_{j}\right)$ を求めるためには，式（2）におけるもう1つの環 境パラメー夕 $k_{j}$ を得る必要がある.このパラメー 夕は前述のように買物吸収密度であるが，これは小 壳業の売場面積 $1 \mathrm{~m}^{2}$ 当たりの買物トリップ数と定 義され，消費者の買物トリップに対する小売業の吸 引能力を表現するものである，従来の研究では買物

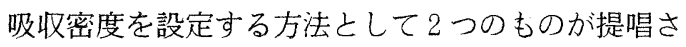
れていた. 1 つは, 研究対象地域全体をとおして統 一的な買物吸収密度を導出する方法であり，もう 1 つは各地区ごとに異なる買物吸収密度を求める方法
である、しかしながら，この 2 つの方法で導かれる 買物吸収密度はいずれも主観的に決められるもので ある。

本研究では, 買物吸収密度と小売業単位コス卜と の関係からみて異なる性格をもつ地域ごとに各区を 分類し，まとめられた地域ごとに買物吸収密度を設 定するという方法を用いる。これは，買物吸収密度 が東京都では地区によって相当变動すること，しか し，その変動は何らかの地区群ごとに一定している こと，および，このようなことは各区の小売単位コ ストに関連すると想定できるからである。ここでの 小売業単位コス卜は, 小売業の売場面積 $1 \mathrm{~m}^{2}$ 当た りの年間販売額と定義され，消費者の購買支出に対 する小売業の吸引能力を表現するものである．買物 吸収密度と小売業単位コストとの関係をグラフ上に プロットすると第 4 図のようになる。この図は横軸 に各区の買物吸収密度, 縦軸に各区の小売業単位コ ストをとり，両者の関係を示したものである，両者 の相関係数 $(R)$ は一 -0.81 となり，マイナスの高相 関があることがわかる。

第 4 図に基づくと, 東京都 23 区を次の 3 つの地 域に分類することができる，すなわち，(1）小壳業 単位コストが非常に高く, 買物吸収密度が非常に低 い地域：千代田・中央・港，（2）小売業単位コス卜 が低いが，買物吸収密度が非常に高い地域：大田・ 杉並・練馬・板橋・足立・江戸川など，（3）これら 2 地域の中間にあり，小売業単位コストが前者の地 域ほど高くなく，買物吸収密度が後者の地域より低 い地域 : 新宿・豊島など, である。

このような3 地域のうち，（1）の地域は，いわゅ る都心といわれている地域であるが，東京の都心商 店街は単に規模が大きいということにとどまらず, 他の地区，たとえば，住宅地区内の商店街とは異な った性質をもっている，都心への消費者は，高級あ るいは特殊な商品を求める人が多いため, 1 回の買 物トリップの平均消費額6が他区より高い，さらに， 
都心の各区の住民は比較的少数であり，自地区内の 消費者の吸収率7)は非常に低い，周辺部の（2）の 地域においては，この地域の住民は通常は近くの住 宅地に点在する商店街において日常的に買物をする。 周辺地域への消費者に関する 1 回の買物トリップの 平均消費額が都心，副都心の地区より低く，自地区 内の消費者の吸収率はすべて高い数值を示す．さら に，周辺地域と都心地域の中間に相当する（3）の 副都心地域は交通線の結節点にあたり，その有利な 位置を利用し, 都心に準ずる高級品と日用品との双 方を備えている，副都心への消費者に関する 1 回の 買物トリップの消費額は周辺地区より高く, 都心よ り低い，自地区内の消費者の吸収率も中位を占める.

以上の分析に加え, 地域の空間的連続性を考慮に 入れると，23 区は第 4 図の点線で示したような 3 地域にグループ化することができる。これら 3 地域 ごとに買物吸収密度を算定すると, 第 1 グループは 0.2967 , 第 2 グループは 0.3618 , 第 3 グループは
0.6864 である。これらの 3 地域それぞれの買物吸 収密度は, 次節における吸収均衡状態方程式 (2) から吸収均衡値の推定に際しての投入变数 $\left(k_{j}\right)$ となる。

\section{2. 吸収均衡値之吸収均衡差の地域分布}

前節において推定された環境パラメー夕 $\alpha, \beta$, $k_{j}$ を採用し，かつ買物吸収トリップ $\left(O_{i}\right)$ 之時間 距離 $\left(c_{i j}\right)$ のデー夕を吸収均衡状態方程式 (2) に 投入して变数 $W_{j}$ を求めた。 この値は, 地区の売場 面積の規模がこの地区に吸収された買物トリップ数 と均衡したときに売場面積がどのようになるかを示 す值であり，吸収された買物トリップに対応してい るため, 吸収均衡値あるいは, 吸収均衡売場面積之 呼ばれる.この吸収均衡值を推定する方法として, 従来は, Eilon et al. (1969), Harris and Wilson (1978), Phiri (1980), Clarke (1981，1985) など により準バランス因子法8)が採用されてきた。しか

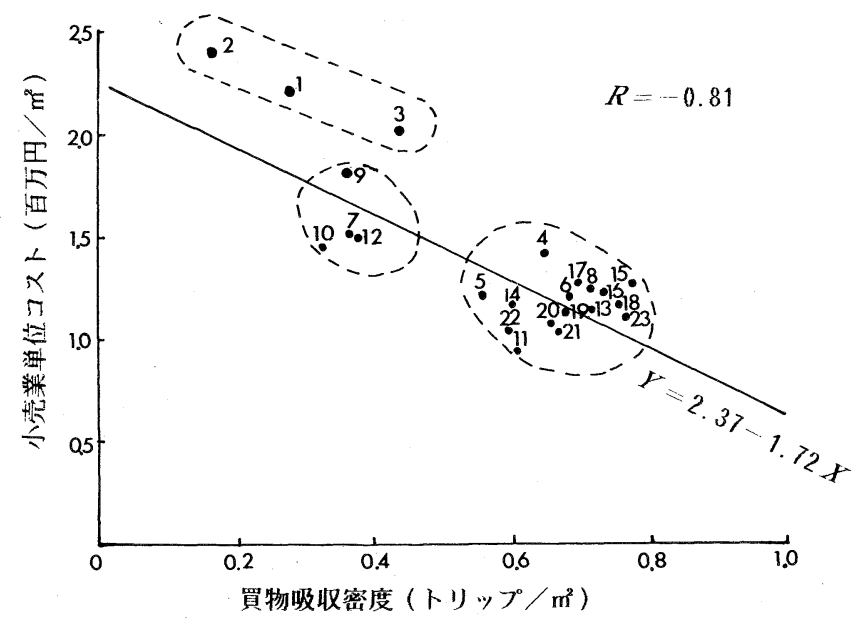

第 4 図東京都区部における買物吸収密度と小売業単位コストとの 関係 (1978 年)
1. 千代田
2. 中央 3 . 港
4. 目黒
5. 品川
6. 大田
7. 豊島
8. 文京
9. 新宿
10. 涉谷
11. 荒川
12. 台東
13. 墨田
14. 江東
15. 中野
16. 杉並
17. 世田谷
18. 練馬
19. 板橋
20. 北
21. 足立
22. 葛飾
23. 江戸川

Fig. 4 The relationship between the unit capacity of retail facilities and the unit selling cost 


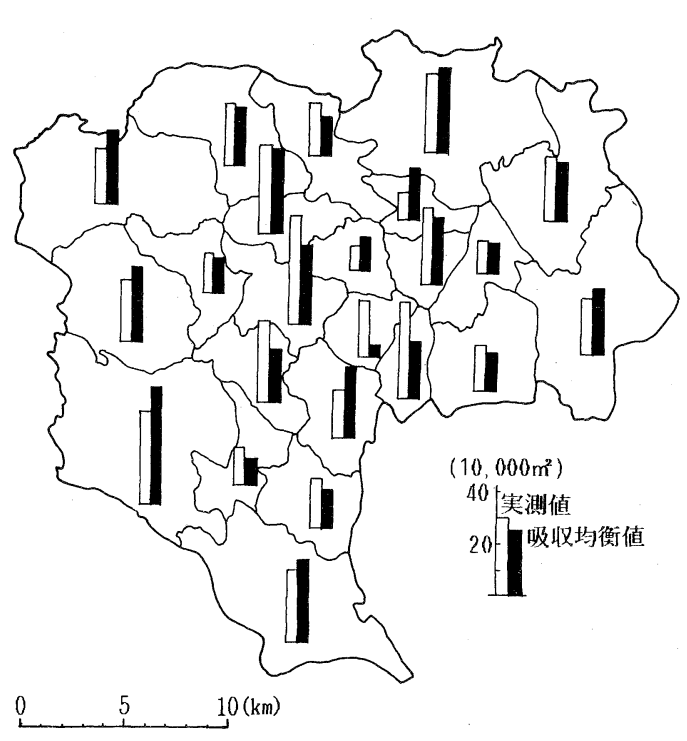

号 5 図東京都区部における売場面積の実測値と吸収均衡 值の地域的分布 (1978 年)

(実測値は, 『商業統計表』(通産省, 1980)による).

'ig. 5 Distribution of the observed shopping floor space and the equilibrium value

しながら、この方法によって求められた吸収均衡値 は, 環境パラメータの変動によって大きな影響を受 け, 吸収均衡値が得られないことがあり, 反復計算 過程で解が発散する可能性もある（Phiri 1980; Crouchley, 1984). そこで, Phiri (1980) はグラデ イエント法やニュートン法などを考案した。本研究 では，より収束がはやい反復計算法の 1 つである修 正ニュートン法9)(深尾, 1972) を用いることにする.

東京都区部における小売業の推定された吸収均衡 売場面積と実際の売場面積との空間的分布を図示す ると，第 5 図のようになる.この図において特徴的 なことは, 都心の 3 区のうち, 千代田区は吸収均衡 值が極端に小であり，それに対して，豊島・新宿な ど副都心区と台東区，杉並・世田谷・大田などの周 辺区は大きな值を示すことである，そして，その中 間に位置する文京・目黒 - 中野 - 品川 - 墨田 - 江東 各区では平均的な值がみられる。これらの吸収均衡 值の分布パターンは, 需給関係が均衡しているとき の小売業立地パターンを示しているので, 千代田区

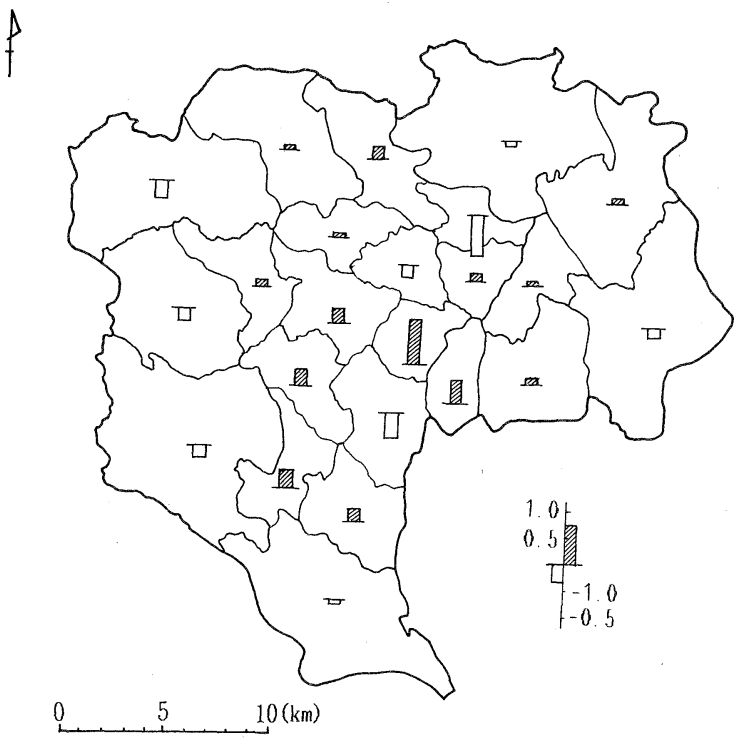

第6図東京都区部における吸収均衡差の分布 (1978 年)

Fig. 6 Distribution of equilibrium difference

においては，買物トリップで示される需要に見合っ た小売業の立地が行なわれるとすれば，そのときの 売場面積は東京都区部では最小のものになるわけで ある，他方，副都心や周辺地域での各区では広い売 場面積が存在することになるといえる．各区の実際 の売場面積を $W^{*}{ }_{j}$, 吸収均衡売場面積を $W_{j}$ とす ると, $\left(W^{*}{ }_{j}-W_{j}\right) / W^{*}{ }_{j}$ で定義される値は吸収均衡 差10)之いわれる。第 6 図はこの吸収均衡差の分布図 である。この図をみると，全体的に大きなプラスの 吸収均衡差が東京都の中心部に分布しており, 周辺 地域, 周辺地域と中心地域との間に位置する一部の 区にマイナスの吸収均衡差が広がっている。そのう ち千代田・中央・新宿・渋谷・目黒の各区はす心゙て 0.3 以上の吸収均衡差をもっているのに対し，荒 川・港・世田谷・練馬などの各区はマイナスの大き な吸収均衡差を有している。これは後者の各区では, 実際の壳場面積は吸収均衡壳場面積に対してやや不 十分な状態にあることを意味している。ただし，大 田・豊島・墨田・板橋・足立の各区においては吸収 
均衡差が小さいので, 実際の売場面積と吸収均衡売 場面積との間には大きな格差がないといえる。なお， 新宿区を中心とする地区から西方，および千代田区 と中央区を中心とする地区から東方に向かって，そ れぞれ吸収均衡差が次第に聥減している.この傾向 から, 東京都区部における吸収均衡差の地域性は, 千代田・中央および新宿の 3 つの心区から伸びる
2つのセクター状をつくるようなかたちで展開して いることが認められる.

3. 吸収均衡差に関連する社会・経済的特性

1）吸収均衡差に関連する社会・経済的特性要素 の抽出

第 1 章で述べたように, 吸収均衡差の地域的変動

第 2 表吸収均衡差に関連する社会・経済的特性の要素とその平均値・ 標準偏差(1978 年)

Table 2 Mean and standard deviation of socio-economic factors related to equilibrium difference

\begin{tabular}{|c|c|c|c|c|c|}
\hline 変 & 数 & 要 & & 平均 $(\mathrm{m})$ & 標準偏差(s) \\
\hline $\begin{array}{l}\text { 小 } \\
\text { 売 } \\
\text { 業 }\end{array}$ & $\begin{array}{l}1 \\
2 \\
3 \\
4 \\
5\end{array}$ & 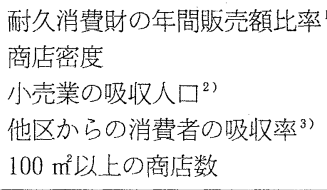 & $\begin{array}{l}\left.\text { ( } \mathrm{m}^{2} / 人\right) \\
\text { (人) } \\
\text { (軒) }\end{array}$ & $\begin{array}{l}0.3100 \\
0.94 \\
366,237 \\
0.223 \\
166\end{array}$ & $\begin{array}{l}0.1002 \\
0.91 \\
205,476 \\
0.1655 \\
62\end{array}$ \\
\hline 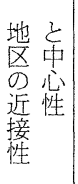 & $\begin{array}{l}6 \\
7\end{array}$ & $\begin{array}{l}\text { 来区の平均時間距離 } \\
\text { 来区の時間距離の標準偏差 }\end{array}$ & $\begin{array}{l}\text { （分） } \\
\text { （分） }\end{array}$ & $\begin{array}{l}50.6 \\
16.0\end{array}$ & $\begin{array}{l}6.3 \\
2.3\end{array}$ \\
\hline $\begin{array}{l}\text { 犬 } \\
\text { 型 } \\
\text { 店 }\end{array}$ & $\begin{array}{l}8 \\
9\end{array}$ & $\begin{array}{l}\text { 大型店の売場面積 } \\
\text { 大型店の支持人口 }\end{array}$ & $\begin{array}{r}\left(\mathrm{m}^{2}\right) \\
\left(人 / \mathrm{m}^{2}\right)\end{array}$ & $\begin{array}{r}58,583.6 \\
14.2\end{array}$ & $\begin{array}{r}70,488.9 \\
16.9\end{array}$ \\
\hline
\end{tabular}

1）通産省『商業統計表』により, 各種商品小売業は織物・衣服・身の回り品, 飲食 料品, 自動車・自転車, 家具・建具・什器, その他の小売の五つの種類に分類さ れる.ここでの耐久消費財の年間販売額比率は織物・衣服・身の回り品, 自動車 部品・自転車, 家具・建具・什器の 3 種類の商品の年間販売額が小売業年間総販 売額に占める割合である.

2）小売業の吸収人口は，東京都区部の総人口を区の小売業年間販売額シェアに乗じ た值である.すなわち，次の式によって求められる.

$$
P_{j}=\frac{R_{j}}{R} P
$$

$P_{j}$ は区 $j$ の小売業の吸収人口, $R_{j}$ は区 $j$ の小売業の年間販売額, $R$ は東京都区 部の小売業の年間販売額, Pは東京都区部の総人口である。ここでは, 『商業統計 調查報告書』,『東京都統計年鑑』（東京都, 1980）を用いて小売業の吸収人口を算 出した.

3）他区からの消費者の吸収率 $=1$-自区内の消費者の吸収率

$$
=1-\frac{T_{j j}}{\sum_{i} T_{i j}}
$$

4）東京都区部の, 大型店は売場面積 $3,000 \mathrm{~m}^{2}$ 以上の百貨店, スーパー, ショッピン グセンター, 共同店, 生協なぞである. 大型店の資料は, 『地域経済総覽』(東洋 経済新報社, 1979）によった。

5）大型店の支持人口は，大型店売場面積 $1 \mathrm{~m}^{2}$ 当たりの小売業の吸収人口と定義され る. 大型店の資料は, 『地域経済総覧』（東洋経済新報社, 1979）により，小売業の 吸収人口は, 注2）を参照した。

6) 平均值之標準偏差は, 『商業統計表』(通産省, 1980), 『商業統計調査報告書』(東 京都, 1980), 『地域経済総覽』(東洋経済新報社, 1979) のデータから計算した. 
第 3 表 吸収均衡差の規定要因に関する逐次回帰分析

Table 3 Step-wise regression analysis between the equilibrium difference and socio-economic factors

\begin{tabular}{|c|c|c|c|c|}
\hline 説 明変 数 & 偏回帰係数 & 標準偏回帰係数 & $F$ 値 & 有意水準 \\
\hline $\begin{array}{l}\text { 耐久消費財の年間販売額比率 } \\
\text { 大型店の支持人口 } \\
\text { 小壳業の吸収人口 } \\
\text { 来区の平均時間距離 }\end{array}$ & $\begin{aligned} & 3.8071 \\
- & 0.0044 \\
- & 0.00000068 \\
& 0.0172\end{aligned}$ & $\begin{array}{r}1.0199 \\
-0.4321 \\
-0.4050 \\
0.3114\end{array}$ & $\begin{array}{r}11.28 \\
5.29 \\
2.38 \\
1.87\end{array}$ & $\begin{array}{l}0.0035 \\
0.0337 \\
0.1407 \\
0.1886\end{array}$ \\
\hline $\begin{array}{r}\text { 定数 } \\
\text { 重回帰係数 } \\
\text { 決定係数 } \\
F \text { 值 } \\
\text { 有意水準 }\end{array}$ & $\begin{aligned}-1.2403 \\
0.7556 \\
0.5709 \\
5.99 \\
(0.0030)\end{aligned}$ & & & \\
\hline
\end{tabular}

をもたらす原因については，従来の研究においてい まだ指摘されていない，本節では，東京都区部レべ ルにおいて吸収均衡差に関連する社会・経済的特性 を検討し，前節で明らかにした吸収均衡差（すなわ ち, 実際の売場面積と吸収均衡売場面積との差）の 分布パターンの形成要因について考察を加える.

吸収均衡差に関連すると考えられる社会・経済的 特性の要素は, 商業地域に関する多くの実証的研究 （荒井, 1981 ; 伊東, 1982 ; 藤井, 1983 ; 香川, 1987）の成果に基づけば，小売業の属性，地区の中 心性之近接性, 大型店の属性の 3 つに大別される. これを具体的に表現する指標として，ここでは第 2 表に示すように 9 個の变数を取り上げた。吸収均衡 差に関連する社会・経済的特性の要素としてこれら 9 变数を採用する理由は, 9 個の变数の一部が小売 業自体の特徵を示し，またその一部が消費者の買物 行動に影響を与える要因と考えられ，その特徴と要 因が，吸収均衡値のバランスメカニズムの形成要因 と関連しているからである。

これらの变数を説明变数, 吸収均衡差を目的変数 とする逐次回帰分析（奥野ほか，1971）を行なう. ただし，最適回帰モデルの構築に際しては，最大 $R^{2}$ 改良の逐次回帰法を適用した。 その結果は第 3 表のとおりである.

吸収均衡差に顕著な影響を与える社会・経済的要
素は, 9 個の变数のうち, 耐久消費財の年間販売額 比率, 大型店の支持人口, 小売業の吸収人口，来区 の平均時間距離の 4 要素であるといえる. 4 要素の なかで最大の標準偏回帰係数をもつ要素, つまり吸 収均衡差の地域的变動を最もよく説明する要素は, 耐久消費財の年間販売額比率である，他の要素に関 する相関は，大型店の支持人口，小売業の吸収人口， 来区の平均時間距離の順に低下する。なお回帰分析 の重相関係数は 0.7556 であり, 有意水準は 0.01 に 達する。したがって，この回帰分析は非常に有意で あると結論することができる.

2）吸収均衡差に関連する社会・経済的特性要素 の地域分布

最大 $R^{2}$ 改良逐次回帰法によって選定された 4 要 素の地域的分布は，第 7 図- $\mathrm{a} \sim \mathrm{d}$ に示されるとおり である。耐久消費財の年間販売額比率が $m+\frac{1}{2} s$ 以 上 ( $m$ : 平均值, $s$ : 標準偏差) を示す地域は, 都 心2区（千代田・中央），副都心 3 区と台東区であ り，他の地域はすべて平均值以下である（第 7 図a)。したがって，酎久消費財の年間販売額比率の 地域的分布によれば，東京都区部は2つの地域に分 けられる。これは，大都市において日用消費財の販 売は人口分布の傾向と一致して分散的に分布するも のであり，他方では，耐久消費財の販売はおもに都 心, 副都心で行なわれるという商品販売の地域差に 

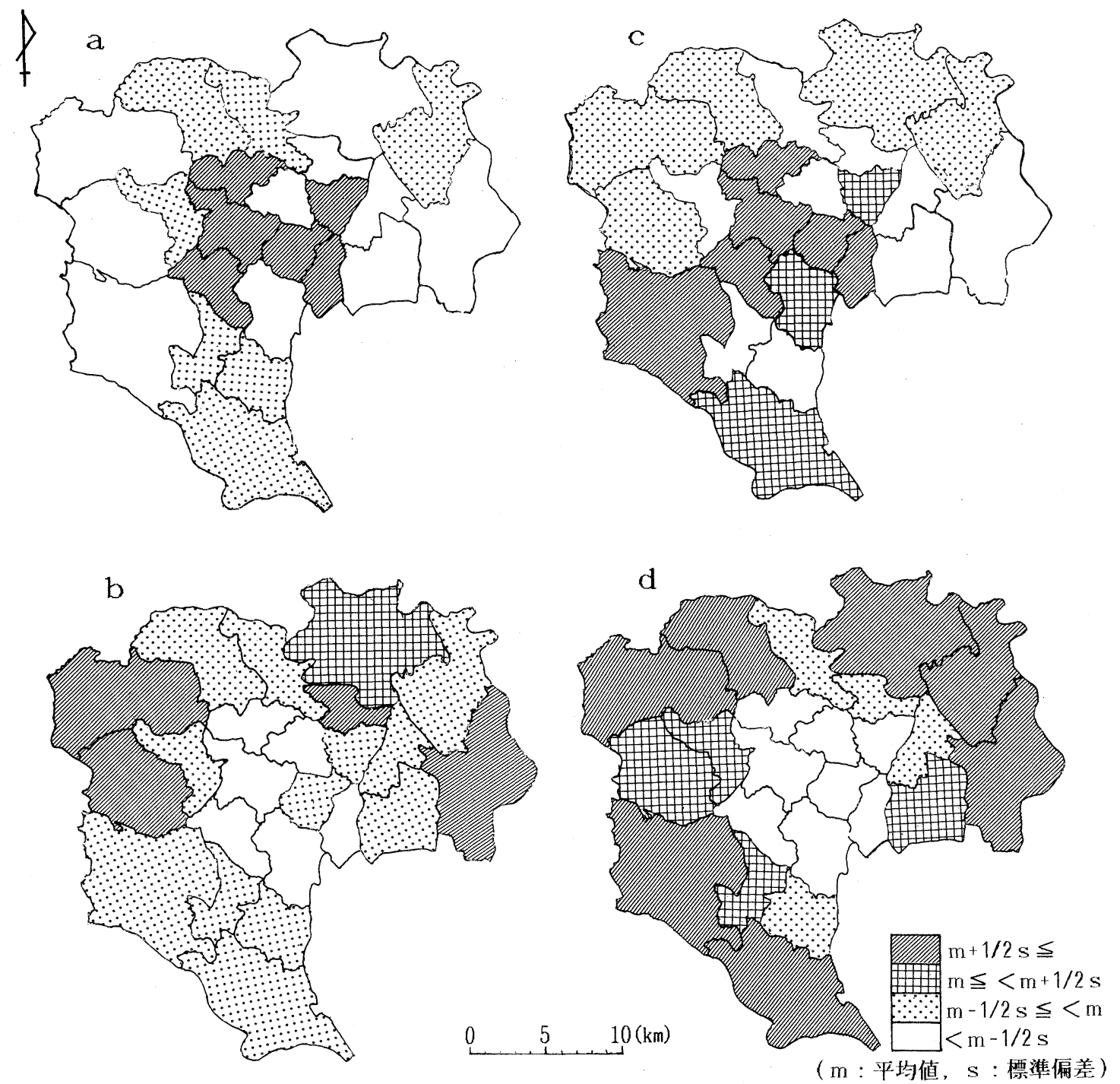

第 7 図 東京都区部の吸収均衡差に関連する社会・経済的特性の 4 要素の分布（1978 年）

a. 耐久消費財の年間販壳額比率 $\quad \mathrm{b}$. 大型店の支持人口 $\quad$. 小売業の吸収入口 $\quad \mathrm{d}$. 来区の平均時間距離

Fig. 7 Distribution of socio-economic factors related to equilibrium difference

よって生じたものであるといえる，耐久消費財の年 間販売額比率に関する偏回帰係数はプラスの值であ

る.このことから，耐久消費財の年間販売額比率の 増大に伴って吸収均衡差も増大するといえる. それ は，1人の買物客に対して耐久消費財の小売店の売 場面積が日用消費財の小売店より大きいため, 耐久
消費財の年間販売額比率の高い地区では，吸収均衡 売場面積よりかなり大きな実際の売場面積を保有し ていることを表明した。

大型店の支持人口の多い練馬・江戸川などの周辺 区を除き，この支持人口の要素で平均値 $(m)$ 以下 を示す地域は，東京都区部に広く分布している（第 
7 図-b). 中心部の各区での大型店の支持人口は非 常に少ない。たとえば，都心の中央区の大型店の支 持人口は $1 \mathrm{~m}^{2}$ の売場面積に対し 4.4 人にすぎない, 副都心の新宿, 豊島, 渋谷の各区でも大型店売場面 積 $1 \mathrm{~m}^{2}$ 当たりわずか 3.7 人, 2.4 人, 3.7 人である. 他方，これらの区では，小売業吸収力がきわめて強 く，たとえば，中央・新宿・千代田・豊島各区の小 売業吸収人口が平均値の約 $2 \sim 3$ 倍に達する(第 7 図-c).これら 2 要素の偏回帰係数はマイナスの值 をとるため (第 3 表), 全体に大型店の支持人口あ るいは小売業の吸収人口の増加は吸収均衡差の減少 と関連している，それは，大型店の支持人口あるい は小売業の吸収人口の多い地区においては小売施設 が有効に利用され, 過剩な施設が少なくなるため, 害際の売場面積之吸収均衡売場面積之の間には大き な格差がないといえる.これら2要素のもつ吸収均 衡差に対する影響力は耐久消費財の年間販売額比率 の場合より低い。

来区の平均時間距離という要素の分布は, 地区の 配置と都市の交通条件の分布を反映している。東京 都区部において来区の平均時間距離は中心から周辺 へ向かうに従って増加しているが(第 7 図-d), こ れは吸収均衡差にプラスの影響を与える。すなわち， 来区の平均時間距離に関する偏回帰係数はプラスの 值であることから, 来区の平均時間距離の増大によ って, 吸収均衡差は增大するといえる。

以上のことから, 東京都区部における吸収均衡差 の地区別の変動は, 耐久消費財の年間販売額比率, 大型店の支持人口，小売業の吸収人口，来区の平均 時間距離といった社会・経済的特性の諸要素之関連 していることが判明した。

一方, 小売業は, さまざまな社会・経済の外的要 因と人間の意識や行動などの内的要因に関連する複 雑なシステムである。千代田区のような行政, 経済, 文化などの中枢的諸機能が集中している都心地区で は, 小売業の実際の売場面積と吸収均衡売場面積と
第 4 表 買物トリップ発生量に関する 説明変数

Table 4 Explanatory variables related to the shopping trips generated from a zone

\begin{tabular}{l|l}
\hline \multicolumn{1}{c|}{ 要因種類 } & \multicolumn{1}{|c}{ 社会・経済指標 } \\
\hline 規 模 要 因 & $\begin{array}{l}\text { 人口数 }\left(x_{1}\right) \\
\text { 世帯数 }\left(x_{2}\right) \\
\text { 区の面積 }\left(x_{3}\right)\end{array}$ \\
\hline 活 動 要 因 & 小売業年間販売額 $\left(x_{4}\right)$ \\
乗用車保有率 $\left(x_{5}\right)$
\end{tabular}

1) 主要道路は『東京都統計年鑑』（東京都, 1979）のなかに記人されている国道・主 要地方道・般都道を指す.

2）この表の社会・経済指標名は、『東京都統 計年鑑』(東京都, 1979), 『商業統計調查 報告書』（東京都, 1980）による.

の大きな差は，この回帰分析で取り上げた要因によ り部分的に説明できるが，この分析で考慮されてい ない要因にも関連していると考えられる.

\section{III 東京都区部における小売業の均衡的 立地パターンの動態的分析}

買物行動モデルに基づく吸収均衡状態方程式 (2) と上述した吸収均衡差の地域性に関する分析結果を みると, 吸収均衡値之吸収均衡差の变動およびそれ らの地域分布パターンは, 環境パラメー夕 $\alpha, \beta$, $k_{j}$ に関連しているのみならず，地区別の買物卜リ ップ発生量 $O_{i}$ にも関係があると考えられる。ここ では，まず，それらのうち買物トリップ発生量を外 生変数におき, 各地区における買物トリップ発生量 を将来時点について予測する. 次いで，この予測さ れた将来の買物トリップ発生量に基づき, 吸収均衡 状態方程式の環境パラメー夕や他の変数を変動させ て, 吸収均衡値の動態的分析を行なうことにする.

\section{1. 買物トリップ発生量の予測}

買物トリップ発生量の予測にあたっては，その発 
第 5 表 買物トリップ発生量の推定と予測の結果

Table 5 Results of the function model

\begin{tabular}{|c|c|c|c|c|c|}
\hline \multirow[b]{2}{*}{ 区 } & \multirow{2}{*}{$\begin{array}{c}\text { 人口 } \\
X_{1} \\
\text { 1990年 }\end{array}$} & \multirow[b]{2}{*}{$\begin{array}{c}\text { 発生量 } \\
\text { 実績値 } \\
Y \\
Y \\
1978 \text { 年 }\end{array}$} & \multicolumn{3}{|c|}{ モ デル } \\
\hline & & & $\begin{array}{c}\text { 推定値 } \\
\hat{Y} \\
1978 \text { 年 }\end{array}$ & $\begin{array}{l}\text { 残 差 } \\
\text { 比 率 }\end{array}$ & $\begin{array}{l}\text { 予测值 } \\
\text { 1990年 }\end{array}$ \\
\hline 千代田 & 47,089 & 23,776 & 26,303 & 0.106 & 19,122 \\
\hline 中 央 & 76,612 & 41,055 & 35,792 & -0.128 & 29,635 \\
\hline 港 & 187,849 & 66,126 & 76,257 & 0.153 & 69,247 \\
\hline 目 黒 & 267,056 & 96,503 & 98,823 & 0.024 & 97,453 \\
\hline 品 川 & 356,288 & 118,560 & 125,262 & 0.057 & 126,874 \\
\hline 大田 & 665,767 & 243,940 & 241,127 & -0.012 & 239,433 \\
\hline 豊 島 & 275,597 & 108,348 & 104,885 & -0.032 & 100,494 \\
\hline 文 京 & 194, 088 & 77,165 & 75,106 & -0.027 & 71,469 \\
\hline 新 宿 & 328,688 & 125,779 & 124,254 & -0.012 & 119,400 \\
\hline 渋 谷 & 236,062 & 86,540 & 91,593 & 0.058 & 86,416 \\
\hline 荒 川 & 187,689 & 73,857 & 74,966 & 0.015 & 69,190 \\
\hline 台 東 & 172,976 & 91,241 & 72,274 & -0.208 & 63,951 \\
\hline 墨 田 & 227,061 & 95,556 & 87,882 & -0.080 & 83,210 \\
\hline 江 東 & 397,126 & 118,450 & 128,706 & 0.087 & 143,771 \\
\hline 中 野 & 333,035 & 124,090 & 124,047 & 0.000 & 120,948 \\
\hline 杉 並 & 543,682 & 187,987 & 191,748 & 0.020 & 195,959 \\
\hline 世田谷 & 823,462 & 289,873 & 278,917 & -0.038 & 295,588 \\
\hline 練 馬 & 608,304 & 191,296 & 202,094 & 0.056 & 218,971 \\
\hline 板 橋 & 511,431 & 174,923 & 176,514 & 0.009 & 184,475 \\
\hline 北 & 364,145 & 145,186 & 144,848 & -0.002 & 132,026 \\
\hline 足 立 & 629,384 & 226,564 & 225,861 & -0.003 & 226,478 \\
\hline 葛 飾 & 420,106 & 156,012 & 155,540 & -0.003 & 151,954 \\
\hline 江戸川 & 534,234 & 176,504 & 176,430 & 0.000 & $1.92,595$ \\
\hline
\end{tabular}

生量は買物行動に関連する各種の社会的・経済的特 性によって規定されるという考え方に基づいて，そ の特性から買物トリップの発生量を求めることにす

る. この考え方は交通地理学や交通工学（竹内ほか, 1987）において一般的な考え方である.ここでは，

買物トリップ発生量を目的変数, その発生量に影響 を与える社会・経済要因を説明变数とする線形回帰 モデルをある時点について推定し，このモデル内の 諸变数間の関係は異なる時点においても不変である という前提のもとで, 諸変数に関する異なる時点で のデータを投入することによってその時点での買物 トリップ発生量を予測する.

買物トリップ発生量に影響を与える要因は，規模 要因・活動要因・地域特性要因に大別されるが, こ れらについては従来の多くの研究結果 (Mitchell and Rapkin, 1954 ; 佐々木ほか, 1965 ; 奥野, 1965，1966；藤目，1977）を参考にして，第 4 表に 示されるように，それぞれ9個の指標を用いること にする.この 9 個の指標を説明変数として, 逐次回 帰分析を行ない, 買物トリップ発生量の推定モデル をつくると，9個の指標のうち人口のみが有意な説 明变数として採用された下記のようなモデル式が得 られた。 なお，推定モデルのキャリブレーションに 際しては, 1978 年の買物トリップ発生量および 1978 年前後の 9 指標に関する資料を用いた.

$$
\hat{Y}=2353.96+0.3561 x_{1}(R=0.9947)
$$

ここで， $R$ はモデルに関する相関係数であり，き わめて大きな值をとる， $x_{1}$ は，第 4 表に掲げられ ている人口（人）である，このモデルは，従来の研 究が目的別発生交通量, あるいは買物トリップの発 生量と人口との間に密接な関係がある（奥野， 1965 ; 佐々木, 1974 ; 南, 1981）と結論したことと 一致する. 東京都が予測した 1990 年の区別人口 ${ }^{11}$ をこのモデルに投入することによって，1990 年買 物トリップ発生量の予測を行なった．推定結果は第 5 表最右欄のとおりである。これによると, 以下の ことがいえる. 1990 年において都心の千代田・中 央および台東・墨田・北の各区では，人口減少に伴 って買物トリップの発生量が 1978 年に比して大き く減少する一方, 品川・杉並・練馬・板橋・江東・ 江戸川の周辺諸区では人口増加に従って, 買物トリ ップの発生量も増加する。 また, 他の地区では大幅 な変化がみられない。

\section{2. 吸収均衡值の動態的分布パターン}

小売業をとりまく環境が变化すれば，当然のこと ながら，均衡状態にある小売業の立地もその影響を 受けて変化していく，このことは，小売業立地研究 と関係の深い中心地理論に関する動態論を扱った諸 研究 (Stabler and Williams, 1973; Beavon, 


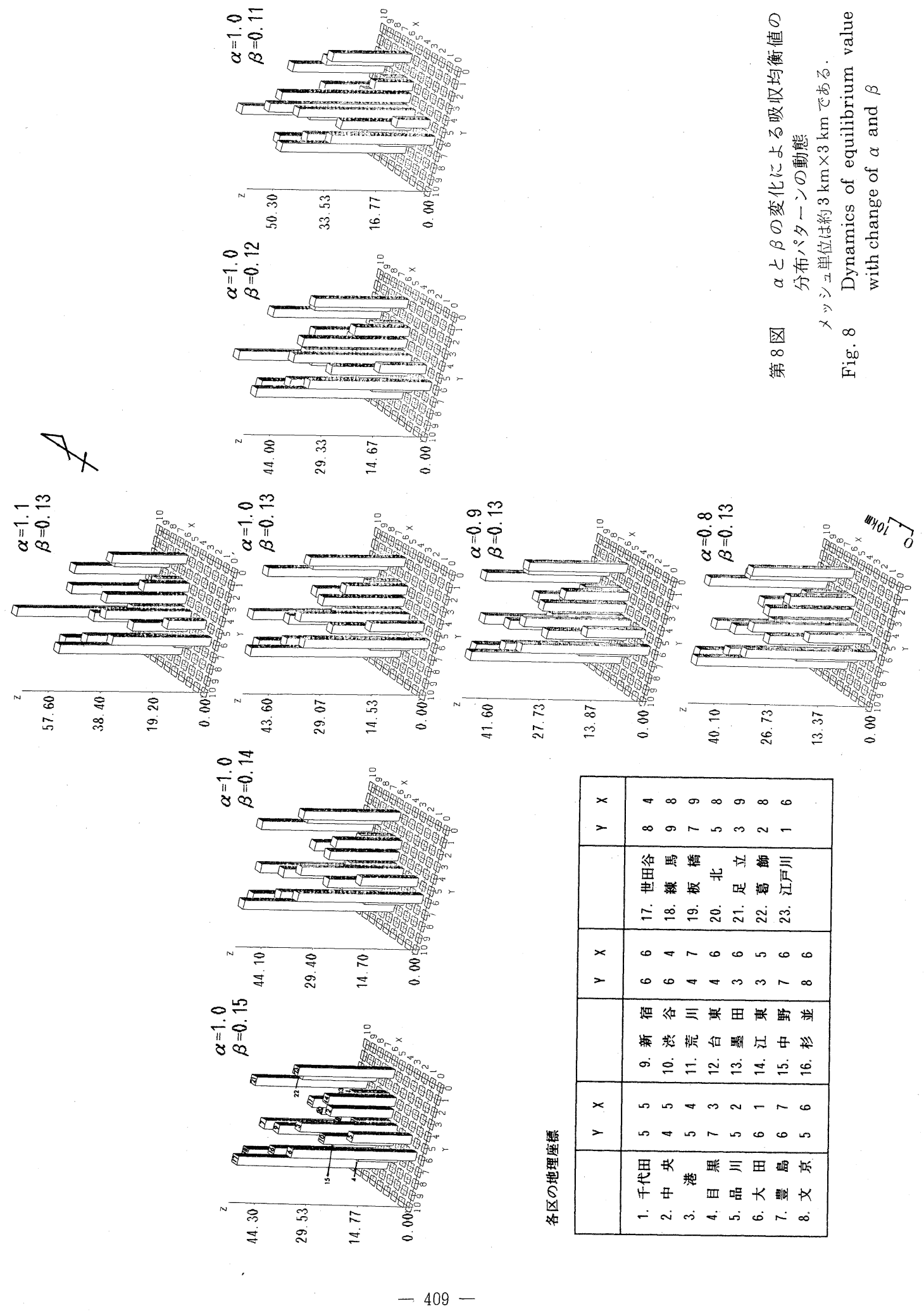


1977; Allen and Sanglier, 1979, 1981) によって も指摘されている。ここでは，この環境の変化には 次の 3 つ側面があると考える。すなわち, (1) 都市 内人口の変化による消費者買物トリップ発生量の変 化, (2) 経済規模の変化, (3) 交通条件の変化である. それらの変化のうち(1)については前節においてす でに求めた（2)と（3）については経済規模パラメー 夕 $\alpha$, 距離減衰パラメー夕 $\beta$, および地区間の時間 距離 $c_{i j}$ それぞれの変化によって表現する. それら の变化によって, 需要と供給の間の関係の均衡状態 を前提とするときの小売業立地パターンを示唆する 吸収均衡值の分布パターンがどのように变化するか に関して, 吸収均衡状態方程式 (2) に基づく数值シ ミュレーションによって，考察を試みる.

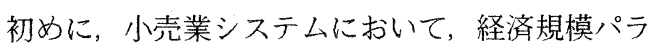
メー夕 $\alpha$, 距離減衰パラメー夕 $\beta$ の变化が吸収均衡 值の分布パターンにいかなる影響を及ぼすかを考察 することにする，第 8 図では， $\alpha=1.0, \beta=0.13$ の場合を中心として, 縦方向に配列された 3 次元柱 状図が $\alpha$ の影響を，横方向に配列された同種の図が $\beta$ の影響を示している. ここでは, 正方形メッシュ を対象地域にかぶせ, これにより, 各地区の地理座 標を決めてある.したがって，3次元柱状図では， 2 次元の空間座標系 $(X, Y)$ がメッシュに対応し, 柱の長さ（これは $Z$ 座標で測られる）が小売業の吸 収均衡売場面積を示している。

1）経済規模パラメータの变化による数值シミュ レーション

パラメータ $\alpha$ は, 式 (2) でみられるように特定 地区の小売業売場面積にかかわるパラメータであり， この売場面積が一定のとき， $\alpha$ が大きいほどその地 区へ流入する買物トリップ数が多いことを意味する. したがって， $\alpha$ は経済規模を計る尺度である，従来 の研究によれば, 大都市における小売業の分布は, 人口分布に対応して周辺地域へ向かうに従って分散 化，平均化していき，さらに，近年の運賃および輸
送コストの上昇は，買物の遠距離化をますます否定 する傾向をもたらしていると指摘されている（荒井, 1981 ; 津川, 1982)。したがって, 経済規模は, 時 間の経過に伴って地域的に平均化し， $\alpha$ は徐々に低 下していくと仮定することができる．この低下傾向 を表現するために, 前章で推定した 1978 年の経済 規模パラメー夕 $\alpha$ 值は 1.2 であるが,この $\alpha$ 值を $1.1 ， 1.0 ， 0.9 ， 0.8$ のように 0.1 ずつ減少させるこ とにする。距離減衰パラメータ $\beta$ 值は常に 0.13 と 固定する.これらの $\alpha, 1978$ 年当時の地区間の時 間距離 $c_{i j}$ および前節で予測された買物トリップ発 生量 $O_{i}$ を吸収均衡状態方程式（2）に投入して, 吸収均衡値を求めた。 その結果は第 8 図のとおりで ある、この図によると， $\alpha$ 值の減少に従って都心に 位置する各区，とくに中央・港区の吸収均衡值はそ れぞ机 30.2 万 $\left(\mathrm{m}^{2}\right.$ : 以下同) から 21.9 万へ，32.1 万から 27.1 万へと激減している。副都心の豊島・ 新宿区でもこのように減少する傾向がみられる。一 方，人口が 40 万以上の周辺各区，たとえば，南部 の大田, 西部の杉並・世田谷・練馬, 北部の板橋, 東部の足立・葛飾・江戸川では， $\alpha$ 値の減少に対す る吸収均衡值の変化はほとんど生じない，また，都 心，副都心亡周辺諸地区の間に位置し，小売業が相 対的に小規模である文京・中野などでは，吸収均衡 值は $\alpha$ 值の減少に伴い増加する傾向がみられる。こ のことから，消費者の経済規模パラメー夕 $\alpha$ 值が減 少するに従って, 商業中心地としての機能をもつ都 心, 副都心の小売業吸収均衡売場面積が隇少する一 方, 小売業規模の比較的小さい地区のそれが増加し, 東京都区部全体において小売業の吸収均衡売場面積 が地域的に比較的集中していた状態から，均一な状 態に変わっていくと考えられる

2）距離隇衰パラメータの变化による数值シミュ レーション

パラメータＢは買物トリップの流動性を計る尺度 として, 距離滅衰パラメータと呼ばれる。 $\beta$ の值は, 
交通の進歩, 生活水準の向上とともに減少する傾向 にある（森川, 1967)。さらに, 従来の研究では, $\beta$ が高い値から低い値へ変化するにつれて, 吸収均 衡値の分布パターンが均一型から凝集型へ变化する と解説されてきた (Clarke and Wilson, 1983). ここでは， $\beta$ の值を 0.15 から 0.01 ずつ聥減させ, 吸収均衡值の分布パターンの变動を考察する.これ らの $\beta, 1978$ 年当時の地区間の時間距離 $c_{i j}$ および 前節で予測された買物トリップ発生量 $O_{i}$ を, 吸収 均衡状態方程式 (2) に投入して, 吸収均衡值を求 めた，その結果は第 8 図のとおりである。この図を 横方向に左から右へみれば, 都心 3 区の吸收均衡壳 場面積 (吸収均衡値) は $\beta$ の減少に伴って急増して いる. 吸収均衡売場面積は， $\beta=0.15$ のときでの 千代田区の 10.0 万 $\left(\mathrm{m}^{2}\right.$ : 以下同) と中央区の 17.9 万から， $\beta=0.11$ のときでの千代田の 45.8 万と中 央区の 42.7 万になり，それぞれ 4.6 倍と 2.4 倍に 増加している．港区の増加が都心 3 区のなかで最も 小さいが, それでも 1.4 倍に達する.また副都心の 豊島区の増加も 1.6 倍以上である。これに対して, 文京・中野・墨田・江東・品川などの諸区では吸収 均衡売場面積は, $\beta$ 值の減少に伴って漸減していく. このことにより, 東京都区部における小売業の吸収 均衡売場面積は, $\beta$ 値の減少に伴い徐々に均一型か ら凝集型へ変動しており,この傾向が従来の研究結 果と一致していることがわかる.

3）地区間の距離の変化による数值シミュレーシ ヨン

交通技術の進歩に伴い, 交通の高速化が進展し, 地区間の時間距離が減少する傾向がある。本研究は, 第 8 図の中心的な場合，すなわち， $\alpha=1.0, \beta=$ 0.13 の場合に対して, 1978 年時間距離 $c_{i j}$ に 0.95 , 0.90，0.85をそれぞれ乗じ，その之きの吸収均衡值 の分布パターンを数值的にシミュレーションするこ とを試みた. 1978 年当時の地区間の時間距離 $\mathrm{c}_{i j}$ に $0.95,0.90,0.85$ を乗じた数值と前節で予測された
買物トリップ発生量 $O_{i}$ を吸収均衡状態方程式 (2) に投入して, 吸収均衡值を求めた。 その結果は第 9 図のとおりである，この図を観察すれば，aからc へ之, $c_{i j}$ が減少するにつれて, 吸収均衡値の分布 パターンが相対的に均一型から凝集型へ変化してい くことがわかる. とくに，都心 3 区では吸収均衡売 場面積の增加が著しく, 距離が最も減少する $\mathrm{c}_{i j} \times$ 0.85 の場合, この 3 区の吸収均衡売場面積が東京 都区部でピークになる. それに対して, 吸収均衡売 場面積の相対的に小さい文京・墨田・江東・中野・ 品川の諸区では一層減少していく.

以上のような数值シミュレーションの結果から, 東京都区部では, 経済規模パラメー夕 $\alpha$ 值の減少に 伴って小売業吸収均衡売場面積が凝集型から均一型 へ変動していくのに対して, 距離減衰パラメータ $\beta$ 值の減少および時間距離 $c_{i j}$ の減少によって, 小売 業吸収均衡売場面積はいずれも均一型から凝集型へ 変動していくことが明らかとなった。

\section{IV おわりに}

本研究は，小壳業に関する需要之供給の間の関係 が空間的に均衡する状態を前提として, 東京都区部 における小売業の立地パターンを導き, その地域的 特徴を考察するとともに，それを基準として現在の 小売業の立地パターンを評価すること, および, 上 述の立地パターンを動態的に分析することを目的と した，前者の問題に関しては，上述の状態つまり空 間的吸収均衡状態（バランスメカニズムともいわれ る）の前提下での小売業立地パターンに対する理論 的研究および誘導方法の考察は従来から行なわれて きたが，これに関連した諸概念および諸方法を操作 的に識別・改良し，それによって小売業の均衡的立 地パ夕ーンを実証的に研究したものはなかった，後 者は, 前者のような研究が成功して初めて行なうこ とが可能となる問題である。

上述の研究目的を達成するに際して，小売業に関 

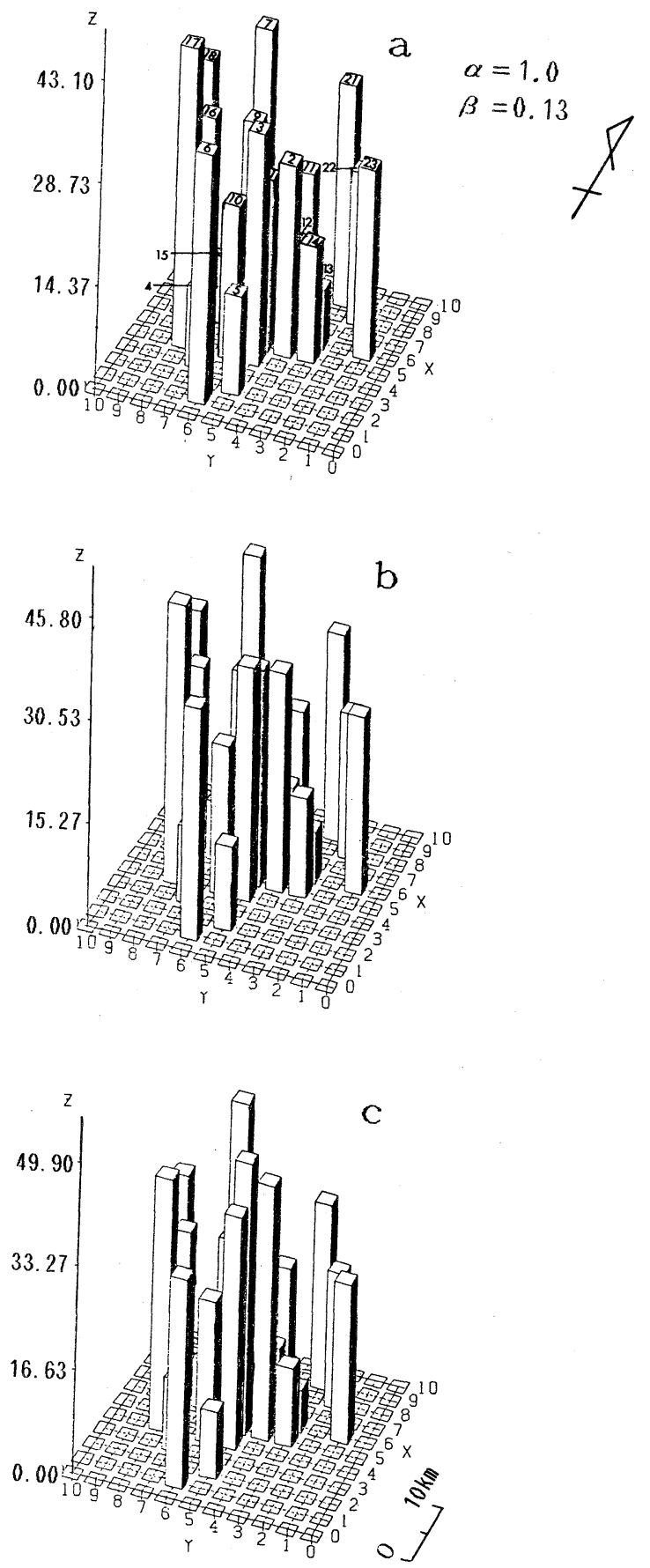

第 9 図時間距離の变化による吸収均衡值の分布パタ ーンの動態

$$
\text { a : } c_{i j} \times 0.95 \quad \text { b : } c_{i j} \times 0.90 \quad \text { c : } c_{i j} \times 0.85
$$

Fig. 9 Dynamics of equilibrium value with change of distance $c_{i j}$
する空間的吸収均衡状態を記述するモデルを利用す る必要があるが, 本研究は, 買物行動モデルに基づ く吸収均衡状態方程式を利用することにした，それ は次の理由による. 吸収均衡状態方程式 (2) では, この式の中間項によって定義される，地区 $j$ に吸収 される買物トリップ数 $D_{j}$ は，地区 $j$ の小売業に対 する需要量, そして最右項における単位売場面積当 たりの買物トリップ数 $k_{j}$ 之小売業売場面積 $W_{j}$ と の積は，地区j の小売業の供給量とそれぞれみなす ことができるからである。吸収均衡状態方程式から 推定される小売業売場面積は吸収均衡値といわれ， その分布パターンは空間的吸収均衡状態のもとでの 小売業の立地パターンを示す. したがって, 本研究 は, 吸収均衡状態方程式に対する; 既存の各種資料 を投入し, 方程式を特定化することから出発した。 本研究によって導かれた諸成果は次のようにま之 めら机る。

（1）初めに, 吸収均衡状態方程式（2）に含ま れる経済規模パラメータ $\alpha$, 距離減衰パラメータ $\beta$ をBaxter-Ewing 法と Nakanishi-Cooper 法によ り推定した. そして, 東京都区部における吸収均衡 売場面積の地域的特徽に影響するおもなパラメー夕 である買物吸収密度 $k_{j}$ と小売業単位コストとの間 の関係に基づいて, 東京都区部を 3 つの地域グルー プに分け, 各地域グループの平均買物吸収密度を算 出した. 次に, パラメータの推定值および地域グル ープの買物吸収密度を吸収均衡状態方程式に投入し, 修正ニュートン法の利用によって吸収均衡值を計算 した。 そして, 吸収均衡差つまり吸収均衡売場面積 と害際の売場面積の差を求めた。この差は地区ごと に異なり, その地域的变動には 1 つの特徵が認めら れた。すなわち，全体的に吸収均衡差が東京都中心 部から周辺部へと減少し，とくに，新宿区を中心と する地区から西方に，また千代田区と中央区を中心 とする地区から東方に向かって, 吸収均衡差が減少 する傾向にあり，2つの中心地区を中心として $2 つ$ 
のセクター状に展開していることが判明した.

（2）吸収均衡差の地域的差異をもたらす要因を 都市小売業属性，地区の近接性之中心性，および大 型店の属性に求め，逐次回帰分析を行なった。その 結果，耐久消費財の年間販売額比率，大型店の支持 人口，小売業の吸収人口および来区の平均時間距離 の各要素が，その要因になっていることが明らかに なった，耐久消費財の年間販売額比率と来区の平均 時間距離の 2 要因の増加は, 吸収均衡差の増大に, 大型店の支持人口と小売業の吸収人口の 2 要因の増 加は，吸収均衡差の低下にそれぞれ関連することが 明確になった。

（3）吸収均衡値の变動は吸収均衡状態方程式パ ラメータの高低に関連するのみならず，各地区の買 物トリップ発生量にも関係すると考えられる．本稿 は人口を説明变数とする買物トリップ発生量の推定 モデルをつくり，このモデルから 1990 年の買物卜 リップ発生量を予測した．各区に関するこの予測値 は人口の変動と密接に関係しており，このことは従 来の研究結果と一致することが判明した.

（4）長距離買物行動の忌避, 距離抵抗の減少, 交通機関の高速化という小売業にかかわる 3 種の環 境变化を想定した，それを経済規模パラメータ $\alpha$, 距離減衰パラメータ $\beta$ ，および各区間の時間距離の 減少で表現した．この仮定のもとで数値シミュレー ションを行ない，吸収均衡値の動態を考察した，数 值シミュレーションの結果により, 経済規模パラメ 一夕 $\alpha$, 距離減衰パラメー夕 $\beta$, 時間距離 $c_{i j}$ の変 化は, 吸収均衡伹の分布パターンの变動に影響を及 ぼしていることが認められた。すなわち，東京都区 部では経済規模パラメータの減少に伴い，小売業の 吸収均衡売場面積の分布が凝集型から均一型へ之变 動していくこと, それに対して, 距離隇衰パラメー 夕の減少，および時間距離の減少によって，小売業 吸収均衡売場面積の分布は均一型から凝集型へと变 化していくことが判明した.
本稿の作成にあたって，筑波大学の奥野隆史教授をは じめとする地球科学系の諸先生方に貴重な御指導をいた だいた，また，同学系の大学院生の皆㥞に有益な助言を いただいた，記して深く感謝いたします。

(投稿 1991 年 10 月 26 日) （受理 1992 年 3 月 14 日）

注

1) 小売の需要一供給の均衡状態は, 他の 2 つのメカ二ズ

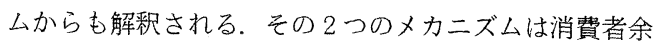
剩最大化之施設規模変化のメカニズムである (Coelho and Wilson, 1976; Wilson and Clarke, 1979; Crouchley, 1987).

（1）消費者余剰最大化のメカニズム：

消費者余㮃を目的関数 Zとして最大化させる.すなわ ち,

$\max Z=-1 / \beta \sum_{i, j} T_{i j} 1 \mathrm{n} T_{i j}+\sum_{i, j} T_{i j}((\alpha / \beta)$

制約条件は $\sum T_{i j}=O_{i}$

$$
\sum_{j}^{j} W_{j}=W
$$

である、ここで，W は対象地域の総売場面積であり， 他の項は前述した買物行動モデル（1）の項と同じであ る.

（2）施設規模変化のメカニズム：

施設規模变化のメカ二ズムは次の微分方程式で表わさ れる.

$$
\frac{\mathrm{d} W_{j}}{\mathrm{~d} t}=\varepsilon\left(D_{j}-k_{j} W_{j}\right)
$$

この式中の $\varepsilon$ はパラメータであり，他の項は前述した 吸収均衡状態方程式（2）の項と同じである.

これらのメカニズムは3つの視点から別々に設定され るが，それらにより求められた吸収均衡値はすべて同一 のものになる (Harris and Wilson, 1978).

2) 前揭注 1).

3） 1978 年に実施された東京都市圏パーソントリップ調 查集計結果の中ゾーン別買物トリップ資料によると，東 京都23区内で吸収される買物卜リップ総数は 3, 269, 469 であり，そのうち，3,039,330 が東京都 23 区から発生 したものであり，約 $93 \%$ を占める.

4) (1) Baxter-Ewing 法:

買物行動モデルを次式（1)，（2）に变形する。

$$
T_{i j}=A_{i} O_{i} W_{j}{ }^{\alpha} \exp \left(-\beta c_{i j}\right)
$$

ただし, $A_{i}=1 / \sum_{j} W_{j}{ }^{a} \exp \left(-\beta c_{i j}\right)$

そして, 地区 $s$ 想定した場合, 他の各地区から発生し, 地区 $S$ に吸収される買物トリップ $T_{i s}$ が非ゼロであれ ば, 次式にみられるように, 式（3）の分子上分母にお ける $A_{i}$ とO $O_{i}$ を約することができる，すなわち， 


$$
\begin{aligned}
\frac{T_{i j}}{T_{i s}} & =\frac{A_{i} O_{i} W_{j}^{\alpha} \exp \left(-\beta c_{i j}\right)}{A_{i} O_{i} W_{s}^{\alpha} \exp \left(-\beta c_{i s}\right)} \\
& =\frac{W_{j}^{\alpha} \exp \left(-\beta c_{i j}\right)}{W_{s}^{\alpha} \exp \left(-\beta c_{i s}\right)}
\end{aligned}
$$

である. 式（3）を対数化すると，

$$
\log \frac{T_{i j}}{T_{i s}}=\alpha \log \frac{W_{j}}{W_{s}}+\beta\left(-c_{i j}+c_{i s}\right)
$$

のような線形式を得る，最後に，デー夕から得られる買 物トリップ数 $T_{i j}$ と $T_{i s}$, 地区間の距離 $c_{i j}$ と $c_{i s}$, 小 売業売場面積 $W_{j}$ と $W_{s}$ を式（4）に代入し，最小 2 乗 法により， $\alpha$ と $\beta$ を推定する.

(2) Nakanishi-Cooper 法:

式 (1) の対数型は

$\log T_{i j}=\log A_{i} O_{i}+\alpha \log W_{j}+(-\beta) c_{i j}$

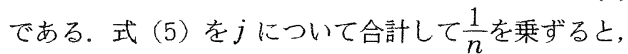

$$
\begin{aligned}
& \frac{1}{n} \sum_{j} \log T_{i j} \\
& =\frac{1}{n} \sum_{j} \log A_{i} O_{i}+\alpha \frac{1}{n} \sum_{j} \log W_{j}+(-\beta) \frac{1}{n} \sum_{j} c_{i j} \\
& =\log A_{i} O_{i}+\alpha \frac{1}{n} \sum_{j} \log W_{j}+(-\beta) \frac{1}{n} \sum_{j} c_{i j}
\end{aligned}
$$

になる，そして，式（5）から式（6）を減ずれば, 線形 式

$$
\begin{aligned}
& \log T_{i j}-\frac{1}{n} \sum_{j} \log T_{i j} \\
& =\alpha\left(\log W_{j}-\frac{1}{n} \sum_{j} \log W_{j}\right)+ \\
& \quad+(-\beta)\left(c_{i j}-\frac{1}{n} \sum_{j} c_{i j}\right) .
\end{aligned}
$$

を得る.したがって, データからの買物トリップ数 $T_{i j}$, 地区間の距離 $c_{i j}$, 小売業売場面積 $W_{j}$ を式 (7) に代 入して，最小 2 乗法によって， $\alpha$ と $\beta$ を推定することが できる.

この両方法を実際に利用する際に問題となることは,

$T_{i j}$ のデー夕にゼロがあると, 解が得られなくなること である．これを回避するために， $T_{i j}$ のデー夕值として 微小な值をあててこれを非ゼロ化する。

5) ゼロの $T_{i j}$ にあてる微小な值の相違は, パラメータ $\alpha ， \beta$ 推定に大きな影響を与えることが予想できるが, ここでは， 50 倍の大きな差をもつ 0.5 あるいは 0.01 を $T_{i j}$ にあてることにして, 両パラメータの推定結果を考 察する。

6) 1 回の買物トリップ当たりの平均消費額=

$$
\begin{aligned}
& =\frac{1}{365} \times \frac{\text { 売場面積 } 1 \mathrm{~m}^{2} \text { 当たりの年間販売額 }}{\text { 売場面積 } 1 \mathrm{~m}^{2} \text { 当たりの買物トリップ数 }} \\
& =\frac{1}{365} \times \frac{\text { 小売業単位コスト }}{\text { 買物吸収密度 }}
\end{aligned}
$$

この式と第 4 図によると, 1 回の買物トリップでの平均
消費額が第 4 図の各点のタンジェント（正接）に正比例 する。

7）自地区内の消費者の吸収率とは，地区 $j$ に吸収される 買物トリップ総数に対する地区 $j$ から発生し自地区に吸 収される買物トリップ数の比率である。すなおち,

自地区内の消費者の吸収率 $=\frac{T_{i j}}{\sum_{i} T_{i j}}=\frac{T_{i j}}{D_{j}}$

それゆえ，自地区内の消費者の吸収率が小さい場合， 他地区からの消費者が比較的多い。これに対して自地区 内の消費者の吸収率が大きい場合，他地区からの消費者 が少なく，消費者はほとんご自地区に住んでいる住民で あることがわかる。

8 ）準バランス因子法は, 非線形連立方程式の解を求める 反復解法として次のような手続きで行なわれる。

ステップ1. $W_{j}$ は任意の初期值 $W_{j}{ }^{(0)}$ をとり, $W_{j}{ }^{(1)}=W_{j}{ }^{(0)}$ 之設定する.

$$
\begin{aligned}
\text { ステップ2. } & D_{j}{ }^{(m)}=\sum_{i} T_{i j}{ }^{(m)}=\sum_{i}\left[O_{i}\left(W_{j}{ }^{(m)}\right)^{\alpha}\right. \\
\cdot & \left.\exp \left(-\beta c_{i j}\right) / \sum_{j}\left(W_{j}{ }^{(m)}\right)^{\alpha} \exp \left(-\beta c_{i j}\right)\right] \\
& \text { を計算し, } D_{j}{ }^{(m)} \text { を } k_{j} \text { で除した值を } \\
& W_{j}{ }^{(m+1)} \text { とする. }
\end{aligned}
$$

ステップ $3 . W_{j}^{(m+1)}$ と $W_{j}^{(m)}$ を比較し, あらかじめ 指定された微小な $\varepsilon$ に対して

$$
\left|W_{j}{ }^{(m+1)}-W_{j}{ }^{(m)}\right|<\varepsilon
$$
が成り立てば，1 つの最適解を求める。 そ うでなければ, $m+1 \rightarrow m$ とおいてステッ プ 2 に戻る。

9 ）修正二ュートン法は，一般に非線形連立方程式の解を 求めるのに用いられる反復計算法であり, 本研究におけ る吸収均衡状態方程式に則するならば，次のように展開 される.

$$
\boldsymbol{W}^{(m+1)}=\boldsymbol{W}^{[m]}-\boldsymbol{A}^{[m]}\left(\boldsymbol{J}^{[m]}\right)^{-1} \boldsymbol{F}^{(m)}
$$
ただし，

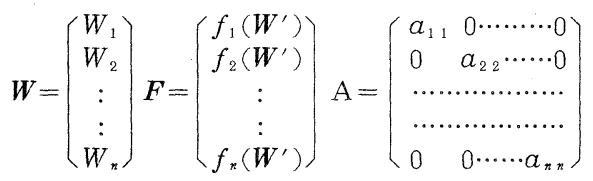

$$
\begin{aligned}
& \boldsymbol{J}=\left(\begin{array}{l}
\partial f_{1} / \partial W_{1} \cdots \cdots \partial f_{1} / \partial W_{n} \\
\cdots \cdots \cdots \cdots \cdots \cdots \cdots \cdots \cdots \cdots \cdots \cdots \cdots \cdots \\
\partial f_{n} / \partial W_{1} \cdots \cdots \cdot \partial f_{n} / \partial W_{n}
\end{array}\right)
\end{aligned}
$$

ここでは，Jはヤコビアン行列であり， $J^{-1}$ はそれの逆 行列である.これのn次ベクトルFは

$$
\begin{gathered}
f_{j}\left(\boldsymbol{W}^{\prime}\right)=\sum_{i} \frac{O_{i} W_{j}{ }^{\alpha} \exp \left(-\beta c_{i j}\right)}{\sum_{j} W_{j}{ }^{\alpha} \exp \left(-\beta c_{i j}\right)}-k_{j} W_{j} \quad \text { (3) } \\
j=1,2, \cdots, n
\end{gathered}
$$

となる要素より構成されている。なお，

$$
a_{j}=\frac{\left|W_{j}{ }^{(m+1)}-W_{j}{ }^{(m)}\right|}{\left|W_{j}{ }^{(m)}-W_{j}{ }^{(m-1)}\right|} \quad j=1,2, \cdots, n
$$


によって計算される $a_{j}$ が， $a_{j} \geqq 1$ あるいは $a_{j}<1$ にな る場合がある．前者の場合は $a_{j}=1$, 後者の場合は $a_{j j}=a_{j}$ として, 值 $a_{j j}$ を $j$ 番目の対角成分として対 角行列 $A$ をつくる．また， $m+1, m, m-1$ はそれぞ れ $m+1$ 回目, $m$ 回目, $m-1$ 回目の反復計算の順序を 表わす. 以上の推定法により, $\left|W_{j}{ }^{(m+1)}-W_{j}{ }^{[m]}\right|<\varepsilon$ ( $\varepsilon$ は非常に小さい数を示す) の条件を満足すると, $W$; が求められ，その値は吸収均衡状態方程式（2）の吸収 均衡値となる.

10）実際の売場面穔の規模差異の影響を避け, 各地区の吸 収均衡差を比較しうるために，本稿では吸収均衡差を相 対値にする。

11）本稿で用いた人口予測の資料は, 東京都総務局統計部 が行なった 1990 年, 1995 年, 2000 年における東京都の 区市町村別人口予測によった。

\section{文 献}

荒井良雄（1981）: 大都市圈における小売商業の立地動向 と大規模小売店の役割. 東京大学教養学部人文科学科紀 要 73 ・ 人文地理, VII, 15-40.

伊東 理 (1982): 大都市における小売商業の分布と地域 構造一福岡 - 札幌市の比較考察—. 地理学評論, 55 , 614-633.

奥野隆史（1965）: 東京都区部における発生・吸収交通に 関する研究 (第一報). 地理学評論, 38, 426-446. 奥野隆史（1966）：東京都区部における発生・吸収交通に 関する研究 (第二報). 地理学評論, 39, 251-266. 奥野忠一・久米 均・芳賀敏郎・吉沢 生 (1971): 『多变 量解析法』日科技連, $430 \mathrm{p}$.

香川勝俊（1987）：小都市における大型店立地の地域商業 への影響一一小売商業機能と中心商店街への影響を中心 に一一. 人文地理, $39,216-233$.

高阪宏行 (1975) : 消費者買物行動からみたシティー・レ ベル商圈の内部構造. 筑波大学 学位論文, $129 \mathrm{p}$.

佐々木 網 (1974): 『都市交通計画』国民科学社, 448p. 佐々木恒一・河野博忠・蔵下勝行 (1965)：『道路の経済効 果亡投資基準』技術畫院, $117 \mathrm{p}$.

竹内伝史・本多義明・青島縮次郎 (1987)：『交通工学』 鹿島出版社, 290p.

津川康雄（1982）: 京阪神大都市圈内部における構造変容 一人口および小売業を例として——. 人文地理, 34 , $1-20$.

東京都市圈交通計画委員会（1980）:『東京都市圈総合都市 交通体系調查報告書——゚ーソントリップ調查計画編 ——, 587p.

南 縈佑 (1981) : パーソントリップからみたソウル市の 機能地域構造一一将来の予測のための試みとして—.
人文地理, $33,25-42$.

深尾 毅 (1972)：『数値計算法』昭晃堂, $211 \mathrm{p}$.

藤井 正 (1983)：京阪神大都市圏における小売商業機能 の立地変動一一大都市圏の構造变化の一局面一. 人文 地理, 35, 210-232.

藤目節夫 (1977) : 香川中央都市圏における交通流の諸特 性ならびに都市構成との関係に関する研究. 地理学評論, 50, 700-721.

森川 洋 (1967) : 勢力圈設定に関する一考察—岡山県 を例として一一。 人文地理, 19, 31-53.

Allen, P. M. and Sanglier, M. (1979): A dynamic model of growth in a central place system. Geogr. Anal., 11, 256-272.

Allen, P. M. and Sanglier, M. (1981): A dynamic model of growth in a central place system II. Geogr. Anal., 13, 149-164. P. M. アレン・M.サン グリエ，水野 勲訳 (1988) : 中心地システム動態的モ デルーII. 理論地理学ノート, 6, 67-85.

Baxter, M. J. (1979): The application of logit regression analysis to production-constrained gravity models. Jour. Reg. Sci., 19, 171-177.

Baxter, M. J. and Ewing, G. O. (1979): Calibration of production-constrained trip distribution models and the effect of intervening opportunities. Jour. Reg. Sci., 19, 319-330.

Beaumont, J. R., Clarke, M. and Wilson, A. G. (1981a): Changing energy parameters and evolution of urban spatial structure. Reg. Sci. and Urban Econ., 11, 287-315.

Beaumont, J. R., Clarke, M. and Wilson, A. G. (1981b): The dynamics of urban spatial structure: some exploratory results using difference equation and bifurcation theory. Environ. Plann. A, 13, 1473-1483.

Beavon, K. S. O. (1977): Central place theory: a reinterpretation. Longman, London, 157p.

Clarke, M. (1981): A note on the stability of equilibrium solutions of production-constrained spatial intercation models. Environ. Plann. A, 13, 601604.

Clarke, M. (1985): The role of attractiveness functions in the determination of equilibrium solutions to production-constrained spatial interaction models. Environ. Plann. A, 17, 175-183.

Clarke, M. and Wilson, A. G. (1983): The dynamics of urban spatial structure: progress and problems. Jour. Reg. Sci., 23, 1-18.

Coelho, J. D. and Wilson, A. G. (1976): The opti- 
mum location and size of shopping centres. Reg. Stud., 10, 413-421.

Crouchley, R. (1984): Equilibrium conditions and solution procedures for the production-constrained spatial interaction model with a general attractiveness function. Environ. Plann. A, 16, 821-828.

Crouchley, R. (1987): An examination of the equivalence of three alternative mechanisms for establishing the equilibrium solutions of the production-constrained spatial interaction model. Environ. Plann. A, 19, 861-874.

Eilon, S., Tilley, R. P. R. and Fowkes, T. R. (1969): Analysis of a gravity demand model. Reg. Stud., 3, 115-122.

Fotheringham, A. S. (1983): A new set of spatialinteraction models: the theory of competing destinations. Environ. Plann. A, 15, 15-36.

Fotheringham, A. S. and Knudsen, D. C. (1986): Modeling discontinues change in retailing systems: extensions of the Harris-Wilson framework with results from a simulated urban retailing system. Geogr. Anal., 18, 295-312.

Harris, B. and Wilson, A. G. (1978): Equilibrium values and dynamics of attractiveness terms in production-constrained spatial interaction models. Environ. Plann. A, 10, 371-388.

Harris, B., Choukroun, J-M. and Wilson, A. G.
(1982): Economies of scale and existence of supply-side equilibria in a production-constrained spatial-interaction model. Environ. Plann. A, 14, 823-837.

Mitchell, R. B. and Rapkin, C. (1954): Urban traffic: a function of land use. Columbia Univ. Press, New York, 226p.

Nakanishi, M. and Cooper, L. G. (1974): Parameter estimation for a multiplicative competitive interaction model-least squares approach. Journal of Marketing Research, 11, 303-311.

Phiri, P. A. (1980): Calculation of the equilibrium coniliguration of shopping facility sizes. Environ. Plann. A, 12, 983-1000.

Stabler, J. C. and Williams, P. R. (1973): The changing structure of the central place hierarchy. Land Economics, 49, 454-458.

Stetzer, F. (1976): Parameter estimation for the constrained gravity model: a comparison of six methods. Environ. Plann. A, 8, 673-683.

Wilson, A. G. (1974): Urban and regional models in geography and planning. John Wiley and Sons, London, 418p.

Wilson, A. G. and Clarke, M. (1979): Some illustrations of catastrophe theory applied to urban retailing structures. London Pap. in Reg. Sci., 10, 5-27. 


\title{
An Analysis of the Equilibrium Locational Pattern of Retail and Its Dynamics in Tokyo
}

\author{
Chang-Ping Zhang*
}

The primary purpose of this study is to analyze the spatiality and dynamics of equilibrium values of attractiveness terms of a shopping behaviour model and to explain present retail locational patterns in Tokyo's 23-ward area based on the analysis. In this study the balancing mechanism of retail supply and demand is used as a theoretical basis for the analysis. This mechanism can be written as

$$
\sum_{i} \frac{O_{i} W_{j}{ }^{\alpha} \exp \left(-\beta c_{i j}\right)}{\sum_{j} W_{j}{ }^{\alpha} \exp \left(-\beta c_{i j}\right)}=k_{j} W_{j}
$$

where the term on the left side of the equation is the total pulled shopping trips to zone $j$ and the term on the right side is the capacity provided by the retail facilities of zone $j$. The equation is also called the equilibrium equation of attractiveness of a shopping behaviour model.

If this study is treated as an empirical study, the first step is to estimate the equilibrium value $W_{j}$ of retail facilities of each zone in the Tokyo 23-ward area, and then to pursue the reason why the equilibrium value is different from real retail floor space. The second step is to present the dynamics and structure of equilibrium value by numerical simulation. As a result of this study, the following points are summarized:

1. Baxter-Ewing's and Nakanishi-Cooper's ordinary logarithmic least-squares methods were utilized to estimate the scale economies parameter $\alpha$ and the distance parameter $\beta$ included in the equilibrium equation of attractiveness. After the relationship between the unit capacity of retail facilities $k_{j}$ and the unit selling cost was considered, a suitable unit capacity of retail facilities for each area was given. The next step was to calculate the equilibrium values and equilibrium differences of each unit zone using a modified Newton's procedure including the iterative calculation; then regional patterns of equilibrium value and equilibrium difference (Fig. 5, Fig. 6) were given, in which equilibrium difference decreases from the inner part to the outer part of Tokyo.

2. To explain the regional pattern of equilibrium difference, specific zonal attributes relating to the equilibrium difference were sought. After nine socio-economic factors, representing the attributes of urban retail, accessibility between zones, and the attributes of big stores were prepared, a multiple regression was formulated by a step-wise procedure, in which four socio-economic factors (the ratio of durable goods to total sales, the population visiting big stores, the population visiting all stores, the average time of travel to each zone) were included as explanatory variables and the equilibrium difference was a criterion variable. The distribution of those socio-economic factors is mapped in Fig. 7.

3. As preparation for analysis of the dynamics of equilibrium values, a linear function model in which the population was selected as a major explanatory variable was formulated and used to 
calculate the shopping trips generated from each zone in 1990.

4. Some hypotheses of environmental changes in the retail system were assumed: average distance for shopping is shorter, travel is easier, and speed of traffic is faster than before. These hypotheses were expressed in terms of decrease of the scale economies parameter $\alpha$, distance parameter $\beta$ and time distance between zones $c_{i j}$. Based on the thus calculated result and assumed hypotheses, a numerical simulation was executed to display the dynamics of the spatial patterns of the equilibrium values. As a result, with decreasing $\alpha$, the spatial pattern of the equilibrium values changes from the concentrated form to the decentralized form, and vice versa with decreasing $\beta$ and $c_{i j}$.

Key words: Tokyo 23-wards area, balancing mechanism of retail supply and demand, equilibrium value, environmental changes of the retail system 